Zabytkoznawstwo i Konserwatorstwo XLII, Toruń 2011

\title{
Rzeźba Matki Boskiej z Dzieciątkiem ze Zbrosławic w typie simulacrum - badania oraz zagadnienia konserwacji i restauracji
}

\section{Wprowadzenie}

$\mathrm{N}$ iewielka rzeźba przedstawiająca Matkę Boską z Dzieciątkiem, otoczona kultem jako Matka Boska Zbrosławicka, znajduje się obecnie w głównym ołtarzu kościoła parafialnego w Zbrosławicach, miejscowości w województwie śląskim, na południowy zachód od Tarnowskich Gór, założonej w XIII wieku.

Sprowadzenie rzeźby do parafii wiąże się z osobami XIX-wiecznych właścicieli Zbrosławic, przybyłych z Austrii. Samo przedstawienie Matki Boskiej z Dzieciątkiem jest obiektem szczególnym. Figury Madonny i Dzieciątka są zupełnie rozdzielne, kompletnie przyodziane w tekstylne szaty, które jako takie są integralnym i nieodzownym elementem dzieła. Żywy w drugiej połowie XX wieku zwyczaj częstego przebierania rzeźb w różnych okresach liturgicznych roku kościelnego stał się pośrednio, z racji stwierdzonych zniszczeń, przyczyna podjętej w 2010 roku decyzji o poddaniu przedstawienia Matki Boskiej Zbrosławickiej zabiegom konserwatorskim i restauratorskim (il. 1, 2). 
Unikalność rzeźby jako wyjątkowego obiektu pełniącego funkcje kultowe, jak i stanowiącego rzadkie dobro kultury na terenie Polski zobligowała do wykonania szczegółowych badań konserwatorskich i budowy dzieła ${ }^{1}$. Zarazem jedynie na podstawie rezultatów przeprowadzonych analiz możliwe było odtworzenie materialnej historii obiektu, a tym samym wyodrębnienie kolejnych opracowań polichromii, precyzyjne określenie ich stanu i ustalenie przyczyn zmian, jakim uległy, gwarantujące optymalny wybór środków i metod postępowania konserwatorskiego. Wiedza zdobyta w toku badań pozwoliła na wybór opcji restauracji i aranżacji dzieła, stanowiącego kompleksową całość złożona z różnorodnych elementów, istotnych dla jego sfery znaczeniowej.

Poczynione ustalenia i wynikające $z$ nich decyzje stały się inspiracją do przygotowania niniejszego opracowania. Jego celem jest przybliżenie, na omawianym przykładzie, problematyki rzadkich na terenach polskich przedmiotów kultowych, wpisujących się w dziedzictwo kultury popularnej, łączących cechy rzeźby polichromowanej i obiektu etnograficznego, pełniących przy tym nadal istotne funkcje sakralne.

\section{Pochodzenie i dzieje rzeźby Matki Boskiej z Dzieciątkiem ze Zbrosławic}

Przedstawienie Matki Boskiej Zbrosławickiej do czasu przekazania jej w 2010 roku do konserwacji-restauracji i badań nie zostało specjalistycznie opracowane w literaturze. Jedynym dostępnym źródłem informacji na jego temat były wiadomości zebrane i opisane przez proboszczów zbrosławickiej parafii - księdza Alfonsa Rymera i księdza Romualda Kokoszkę, a także artykuł w prasie oraz niepublikowany protokół z oględzin obu rzeźb w 1983 roku².

\footnotetext{
1 Szczegółowy opis badań i ich rezultatów oraz relacja z prac konserwatorskich i restauratorskich zob. E. Szmit-Naud, Dokumentacja badań, prac konserwatorskich i restauratorskich rzeźby Matki Boskiej z Dzieciątkiem z Parafii pw. Wniebowzięcia Najświętszej Marii Panny w Zbrosławicach, woj. śląskie, Toruń 2010 [mps].

2 A. Rymer, Sanktuarium Maryjne w Zbrostawicach, 1977; idem, Sanktuarium Macierayństwa NMP w Zbrostawicach, Tarnowskie Góry 1994, s. 13-17; J. Bonczol, U Mat-
} 
Z niedatowanego, opieczętowanego rękopisu księżnej Marii Petroneli Hessen-Darmstadt zachowanego w parafialnym archiwum wynika, że rzeźba Matki Boskiej została przez nią odnaleziona podczas pobytu w klasztorze Dominikanek w Imbach w 1707 roku $^{3}$. Pośrednio danych o losach rzeźby dostarczyła analiza jej budowy oraz stanu zachowania nie podważają one wiarygodności informacji podanej przez księżna.

$\mathrm{Na}$ temat czasu i okoliczności powstania dzieła nie ma żadnych pewnych wiadomości. Ze wzmiankowanej relacji wynika, że mogło ono zostać ukryte na terenie kościoła w Imbach w okolicach Krems wraz z innymi cennymi przedmiotami w obawie przed najeźdźcami, „przed wojna szwedzką" (wojna trzydziestoletnia). Według cytowanego opisu księżnej Marii Petroneli rzeźba została odnaleziona w szacie $\mathrm{z}$,tureckiego sukna z wymalowanymi kwiatami” pomiędzy relikwiami świętego oraz figurami przedstawiającymi apostołów i aniołki, najprawdopodobniej pod deska (w podłodze?) zrujnowanej zakrystii ${ }^{4}$. Jej stan pozwala sądzić, że informacja, iż w momencie odnalezienia stała ona „na jednej drewnianej nóżce”, choć nieścisła, jest prawdziwa - jej lewa noga jest złamana ukośnie w połowie łydki, a odłamana część, mimo że w zasadniczym kształcie zachowana, była już pozbawiona w znacznym stopniu oryginalnych warstw (il. 2, 3). Przekaz księżnej nie zawiera danych dotyczących wyglądu i stanu postaci Dzieciątka w tym czasie, jak i innych możliwych atrybutów rzeźby.

Analiza stylu rzeźby i jej ikonografii oraz porównania z innymi tego typu przedstawieniami ${ }^{5}$ dowodza, że mimo powtarzanego w publikacjach datowania na XIII/XIV wiek ${ }^{6}$, nie należy datować figurki Matki

ki Boskiej Zbrosławickiej, „Gość Niedzielny”, 13 października 1996, nr 41; ks. R. Kokoszka, 700 lat Zbrostawickiej Parafii Najśnietszej Marii Panny w formie kroniki spisanej, Zbrosławice 2005, s. 15, 16, 26; 300 lat temu w Imbach, „Parafianin”, parafia pw. Wniebowzięcia NMP w Zbrosławicach, sierpień 2007, nr 26; Protokół z oględzin figurki Matki Bożej Zbrosławickiej sporządzony dnia 25 stycznia 1983 r., komisja w składzie: ks. Alfons Rymer, Ginter Kaczmarek, Tadeusz Bober, arch. rzeźbiarz [mps].

3 W niniejszym artykule oparto się na tłumaczeniu dokonanym przez ks. Alfonsa Rymera: A. Rymer, Sanktuarium Macieraynnstwa, s. 21-23.

4 Ibidem, s. 22, 23.

5 Dokonane w konsultacji z historykiem sztuki Sławomirem Majochem.

6 Z Imbach istotnie pochodzi rzeźba Madonny z Dzieciątkiem z lat 1320-1330, opisana przez: M. Zykan, Zwei gotische Madonnenstatuen und ibre Restaurierung, 
Boskiej wcześniej niż na początek XVII stulecia, z większym prawdopodobieństwem - na połowę XVII wieku. Mogła ona powstać niedługo przed wzmiankowaną wojną szwedzką. Niewykluczone, że została wykonana przez lokalnego artystę z okolic Krems, może też być importem $z$ innych terenów. Wydaje się, że służyła celom kultowym w obrębie klasztoru. Rzeźba Dzieciątka, która towarzyszy rzeźbie Madonny, jak wykazuje analiza stylistyczna, powstała później, na początku XVIII wieku. Maria Petronela Hessen-Darmstadt mówi w swojej relacji o „Matce Boskiej z Dzieciątkiem”, lecz przedstawienie Dzieciątka najpewniej funkcjonowało wcześniej w innym kontekście, na co wskazują różnice formy oraz warsztatu, czytelne dzięki porównaniu pierwszych warstw polichromii. Rzeźba Dzieciątka mogła pochodzić z przedstawienia stajenki, popularnego w klasztorach. Po połączeniu obu figur w całość ich karnacje zostały ujednolicone wspólnym przemalowaniem.

Księżna za zgodą konwentu zachowała figurkę Matki Boskiej. Przypuszczalnie zadbała o nadanie jej godnego wyglądu, odpowiednio ja wyposażając, m.in. w koronę. Wygląd korony nie pozwala precyzyjnie określić czasu jej powstania - mogła zostać wykonana w drugiej połowie XVII lub w pierwszej ćwierci XVIII wieku. Z zachowanych dokumentów, cytowanych w przywoływanych publikacjach, wynika, że w 1727 roku właścicielka postarała się o poświęcenie figurki Matki Boskiej z Dzieciątkiem (prawdopodobnie tym obecnie zachowanym) w Leopoldstadt koło Wiednia. W dokumencie potwierdzającym poświęcenie rzeźby jest ona opisana jako „figurka Matki Boskiej z Dzieciątkiem Jezus pod Sercem", co należy raczej odczytać dosłownie, jako upozowanie obu figurek - ulokowanie postaci Dzieciątka na łonie Maryi, co jest możliwe dzięki mobilności jej ramion.

„Österreiche Zeitschrift für Kunst und Denkmalpflege”, 1968, Nr. 22, s. 181-184, 187-188. W relacji księżnej dotyczącej tej innej odnalezionej rzeźby może chodzić właśnie o tę gotycką rzeźbę, choć oszacowanie jej rozmiarów nie odpowiada rzeczywistości. Również inne informacje mogą być nieścisłe, m.in. ta, dotycząca rzeźby będącej przedmiotem niniejszego artykułu, że „,cudowna figurka 132 lata temu zagubiła się", co mogło być literackim sposobem nadania jeszcze większej rangi odnalezieniu rzeźby i potwierdzenia jej wyjątkowej wartości.

7 Badania i konserwacja korony zostały przeprowadzone przez dr Katarzynę Wantuch-Jarkiewicz. 
Według informacji przytaczanych przez cytowanych autorów po śmierci właścicielki w 1751 roku jej córka Fryderyka przewiozła figurkę na Górny Śląsk, do Sierot, i przekazała ją kuzynowi z rodu Stockmans, Gustawowi. Po jego śmierci w 1799 roku odziedziczył ją kolejny właściciel dóbr (majątek obejmował Sieroty, Zbrosławice, Wieszowa) jego syn Ernest von Stockmans. Najprawdopodobniej po śmierci żony Ernesta, Elżbiety, w 1823 roku rzeźba Maryi z Dzieciątkiem została umieszczona w miejscu pochówku obojga, w krypcie kaplicy grobowej (kaplicy Najświętszego Serca Pana Jezusa) na przykościelnym cmentarzu w Zbrosławicach ${ }^{8}$. Tam, według ustnej relacji powtarzanej przez ks. Rymera, ja odnaleziono, odziano w nowe szaty i umieszczono na ołtarzu kaplicy kościoła. Istotnie w 1827 roku odnotowano ją w parafialnym inwentarzu jako element wyposażenia, „odzianą w kwiecistą jedwabna szatę, na głowie korona z miedzi mocno pozłacana oraz krzyżyk, ale ze srebra, również mocno pozłacany i wysadzone prawdziwymi rubinami. Do tego jeszcze dwie sukienki, jedna z prawdziwego aksamitu, druga z niebieskiego jedwabiu. Obie obsadzone prawdziwymi złotymi bortami”. Zapisek w inwentarzu z 1850 roku potwierdza cytowany wygląd rzeźby, wymieniając jeszcze płaszczyk z jedwabnej tafty?.

Około połowy XIX wieku staraniem ówczesnego proboszcza Zbrosławic wznowiono odprawianie sobotnich nabożeństw maryjnych ${ }^{10}$. Przedstawienie Madonny z Dzieciątkiem znajdowało się najprawdopodobniej cały czas w kościele, z przerwą spowodowaną jego pożarem i odbudowa w latach 1909-1915, kiedy to ruchome wyposażenie przeniesiono na plebanię.

W 1926 roku ks. Franciszek Nowak opublikował w „Katoliku” informacje zawarte $\mathrm{w}$ odnalezionych przez siebie $\mathrm{w}$ archiwum parafii dokumentach dotyczacych cudownej figurki Matki Boskiej ${ }^{11}$, co ponownie skierowało na nią uwagę wiernych i zaowocowało rozwojem ruchu pielgrzymkowego $^{12}$. Rzeźba znajdowała się wówczas na ołtarzu bocznym,

A. Rymer, Sanktuarium Macierzyństwa, s. 14; ks. R. Kokoszka, op. cit., s. 15.

A. Rymer, Sanktuarium Macieryynstwa, s. 23, 24.

Ibidem, s. 14.

Ks. R. Kokoszka, op. cit., s. 26.

12 A. Rymer, Sanktuarium Macierzyństwa, s. 14. 
z południowej strony nawy. W 1944 roku została przeniesiona z ołtarza bocznego do ołtarza głównego i umieszczona nad tabernakulum. Kolejne odnowienie kultu nastapiło dzięki staraniom ks. Alfonsa Rymera - z jego inicjatywy 8 sierpnia 1954 roku przeprowadzono intronizację, związaną z umieszczeniem rzeźby w zwieńczeniu ołtarza głównego. Prawdopodobnie w latach 70. dokonano przeróbki zwieńczenia, ujmując kasetę z rzeźbą w promienista glorię. Na ożywienie kultu wpłynął ustanowiony w 1955 roku odpust ku czci Matki Boskiej Zbrosławickiej. Z odpustami parafialnymi, tj. ze świętem Wniebowzięcia NMP, wiązał się szczególny sposób ekspozycji Madonny w trakcie uroczystości - noszenie jej w procesjach, na zewnątrz kościoła. Pierwszy raz nastąpiło to w maju 1957 roku, potem corocznie, a wielokrotnie w roku jubileuszowym $1974^{13}$. W okresie późniejszym, przypuszczalnie od końca lat 80., zwyczaj obnoszenia figury w procesji nie był podtrzymywany. W roku 700-lecia Zbrosławic (2005) po raz ostatni figurę wystawiono na ołtarz w kościele i wyniesiono w procesji do ołtarza polowego.

Wzmożenie kultu w XX wieku zaowocowało wykonaniem kompletów nowych szat dla Madonny i Dzieciątka, szytych w parafii ${ }^{14}$. Rzeźby były wielokrotne przebierane $\mathrm{w}$ różnych okresach liturgicznych roku. Szaty wzmiankowane w opisach z XIX wieku najprawdopodobniej nie przetrwały. $\mathrm{Na}$ fotografiach $\mathrm{z}$ drugiej połowy XX stulecia (niedatowanych, zachowanych w parafii) na główce Dzieciątka jest widoczna korona przypominająca w uproszczonej formie koronę Matki Boskiej. Z opisu sporządzonego po przeglądzie z 1983 roku wynika, że wówczas figura Dzieciątka miała już inną koronę o regulowanym obwodzie - ażurową ${ }^{15}$. W 1988 roku ufundowano nową, współczesną złotą koronę dla rzeźby Dzieciątka.

Z przebieraniem i noszeniem rzeźby były związane mechaniczne zniszczenia. Parafianie od lat 70. we własnym zakresie dokonywali napraw.

13 Ibidem, s. 15.

14 Szytych przez siostrę Salezję ze Zgromadzenia Sióstr Opatrzności w Zbrosławicach

15 Odnotowana w Protokole z oględzin figurki Matki Bożej Zbrosławickiej. Przypuszczalnie chodzi już o kolejną koronę z pałkami (bez kabłąka) widoczną na innych fotografiach, m.in. w artykule z $1996 \mathrm{r}$. 
W ich ramach nastąpiło też wykonanie stelażu utrzymującego rzeźbę na cokole, przed 1983 rokiem. W późniejszym czasie dokonano drobnych uzupełnień w niepolichromowanym drewnie.

Dla kościoła w Imbach w Austrii, skąd według źródła pochodzi rzeźba, zostały na prośbę proboszcza tej parafii wykonane kopie rzeźby Madonny i Dzieciątka, funkcjonujące jako przedstawienie Matki Boskiej Zbrosławickiej ${ }^{16}$. Kopię przekazano do Imbach we wrześniu 2006 roku.

\section{Charakterystyka przedstawienia - cechy formalne i zagadnienia ikonograficzne}

Rzeźba przedstawia młodą postać kobieca, która jest niewielka $(45,85 \mathrm{~cm})$, ma ruchoma głowę i ręce złożone z dwóch segmentów - dłoni z przedramionami i ramion - połączonych sznurkiem z korpusem i głowa (il. 2 i 3). Głowa postaci jest nachylona pod niewielkim kątem $\left(13^{\circ}\right)$ do osi szyi, w lewo. Postać stoi w kontrapoście, wspierając ciężar ciała na lewej wyprostowanej nodze, prawą lekko ugiętą w kolanie opiera na uskrzydlonej główce putta, za którym widać fragment obłoku.

Postać jest wysmukła, ma niedużą owalną głowę ( $1 / 7$ wysokości postaci), barki i biodra podobnej szerokości, wysoko wymodelowany (wtórnie) drobny biust i nieco obniżoną talię, lekko wypukły brzuch i niewielkie pośladki. Korpus rzeźby jest częściowo wydrążony, otwór widoczny od frontu nad linią talii ma wykrój w kształcie serca. Wydrążenie zwęża się lejkowato ku dołowi korpusu i jest także połączone otworem z szyją.

Najprawdopodobniej forma dolnej części rzeźby, poniżej stóp, nie zachowała się w pełni. Kształt prawego skrzydła putta sugeruje, że mogło ono być zasłonięte jakimś innym elementem - drugim puttem czy obłokiem tworzącym podstawę rzeźby, bardziej rozbudowaną.

Poszczególne elementy dzieła są wymodelowane z dbałością o detal (np. zaznaczenie paznokci palców stóp widoczne w ubytku), ale bez zbędnego cyzelowania i bez dążenia do symetrii, co uwidacznia się w detalach twarzy oraz zróżnicowanej grubości i długości członków (np. nie-

16 Kopię wykonano w pracowni konserwatorskiej Tadeusza Kalfasa w Węgierskiej Górce na podstawie dokumentacji fotograficznej. 
co masywniejsza lewa noga). Ta niedbałość zdaje się świadczyć nie tyle o nieporadności, ile o swobodzie rzeźbiarza. Owalna twarz ma regularne rysy o spokojnym i pogodnym wyrazie ${ }^{17}$. Czoło wysokie, długi prosty wąski nos o wyraźnie zaznaczonych skrzydełkach, proporcjonalne usta o wydatniejszej dolnej wardze i lekko uniesionych kącikach, nieznacznie cofnięty, nieduży zaokraglony podwójny podbródek, oczy podłużne, nieznacznie wypukłe, o wyraźnie zaznaczonych górnych powiekach, lewe o uniesionym zewnętrznym kąciku. Policzki są lekko zaokraglone, z niewielkimi dołeczkami. Uszy proporcjonalne (wielkości nosa), płasko przylegające do głowy. Krótkie włosy zaznaczone od nasady czoła równoległymi kosmykami sa „,zaczesane” za uszami do tyłu, bez przedziałka, schodzą trójkątnie do górnej linii karku. Taka forma „fryzury” Madonny wyraźnie wskazuje na intencję przykrycia głowy peruką, zastępująca całkowicie realistycznie opracowanie włosów ${ }^{18}$ (il. 2, 3, 4). W szczycie głowy jest otwór (powiększony wtórnie), przesunięty w lewo względem osi, który służył do mocowania korony. Stopy o wysokim podbiciu i lekko zadartych czubkach palców sa średniej wielkości. Nieduże dłonie ( $4 / 5$ wysokości twarzy) miały szczupłe palce, ułożone w nieprzypadkowy gest, możliwy do odczytania dzięki zachowanym fragmentom i odnalezionym analogiom w innych rzeźbach. Główka putta została wyrzeźbiona z mniejszą subtelnością, ale z zachowaniem dużej wyrazistości rysów. Główka i spoczywająca na niej prawa stopa postaci są ustawione wzdłuż tej samej osi, odchylonej w lewo w stosunku do frontu rzeźby (patrząc z przodu). Skrzydło lewe jest rozwinięte, prawe podkurczone, mieści się między główką putta a lewa stopa Madonny. Z obłoku wyrzeźbionego po obu stronach główki putta, za skrzydłami, są dziś zachowane tylko fragmenty. Obecnie do putta jest przymocowany zaokraglony od tyłu

17 Późne przemalowanie, aktualnie pokrywające rzeźbę, rzutuje na odbiór formy; odlew twarzy Madonny wykonany na potrzeby badań pozwolił na obserwacje niezakłócone tymi zniekształceniami.

18 Podobnie są opracowane włosy rzeźby tego samego gatunku, fundacji Paula Esterhazego z 1687 r. z kaplicy zamkowej Forchtenstein - ilustracja w: M. Koller, Kleider machen Heilige. Über Bedeutung und Pflege bekleideter Bildwerke, „Österreichische Zeitschrift für Volkskunde", 1996, L/99, s. 48. 
niewielki klocek z trzpieniem służącym do posadowienia rzeźby na podstawie.

Cechy formalne rzeźby, którą z racji ruchomego wykonania głowy i rąk można nazwać lalką czy manekinem, jednoznacznie sytuuja ją wśród przedstawień zwanych z włoska simulacri da vestire, czyli „symulakrum do ubierania" - tu w znaczeniu religijnych obiektów trójwymiarowo wyobrażających istotę nadprzyrodzona, wyposażonych w atrybuty potwierdzające ich pozorne życie, na przykład możliwość działań motorycznych - poruszanie głowa, rękoma, wyposażonych we włosy (peruka) i przyodziewanych w prawdziwe szaty (bez których najczęściej maja kształt manekinów). Na terenie Polski tego typu przedstawienia, tj. spełniające wszystkie z wymienionych warunków, należą do rzadkości i są obcego pochodzenia. Autorce sa znane jedynie Pietà z Brzegu, pochodząca prawdopodobnie z południowych Włoch, datowana na połowę XVIII wieku, oraz przedstawienie określone jako Rachela z klasztoru Klarysek w Krakowie, pochodzące przypuszczalnie z północnych Niemiec lub Flandrii i wykonane w drugiej połowie XVII wieku ${ }^{19}$. Inne spotykane w Polsce przedstawienia kultowe, wyposażone w szaty, peruki, nierzadko wtórnie, nie mają ruchomych ramion czy głów.

Dążenie do osiagnięcia złudzenia rzeczywistości przez odziewanie wizerunków kultowych jest znane już ze starożytności, „u chrześcijan potrzeba ubierania i przystrajania biżuterią figur otaczanych kultem jako imagines rodzi się z gotykiem"20. Kontrreformacja, reorganizując liturgię i kult świętych, zaczęła z nową siłą „inscenizacyjnie” przedstawiać wizerunki kultowe - prawdziwe tkaniny, włosy i ozdoby podnosiły iluzje prawdziwości oraz powodowały poczucie identyfikacji składających wota i pielgrzymów z danym obrazem kultu ${ }^{21}$. Oprócz przystrajania i dokonywania w tym celu przeróbek wcześniejszych wizerunków, czego przykłady

19 A. Radzimowska, Dokumentacja konserwatorska Pieta, Brzeg 2004; Pax et Bonum. Skarby Klarysek krakowskich, katalog wystawy, Arsenat Muzeum Czartoryskich wrzesień-październik 1999, Instytut Historii Sztuki Uniwersytetu Jagiellońskiego, Kraków 1999, s. 81,82 .

20 M. Koller, Kleider, s. 24.

21 Ibidem, s. 26, 28. 
są znane także w Polsce, tworzono nowe, które od momentu powstania nie mogły funkcjonować bez nakładanych tekstylnych szat czy włosów ${ }^{22}$.

Opisywana rzeźba przedstawiająca Matkę Boską należy właśnie do tego typu dzieł. Opracowanie formy nie pozostawia wattpliwości co do tego, że od momentu powstania była ona wyposażona w perukę i szaty. Możliwy do odczytania gest dłoni sugeruje, że nie ukazano jej w pozie orantki, ale jako Madonnę z Dzieciątkiem, podtrzymująca je lewą dłonia. Zakrzywienie zachowanych fragmentów oryginalnych palców prawej dłoni sugeruje, że między kciukiem a palcem wskazującym i serdecznym ujmowała jakiś przedmiot. Wyposażenie rzeźby w koronę rudolfińską, symbol cesarstwa, wskazuje na intencję królewskiego przedstawienia Madonny; w takim razie przedmiotem trzymanym w dłoni mogło być berło. Dokonanie porównań z innymi zachowanymi przykładami podobnych niewielkich rzeźb symulakrów Matki Boskiej z terenów Austrii ${ }^{23}$, obecnej Belgiii ${ }^{24}$, a także Włoch ${ }^{25}$, pojedynczymi z terenu

22 Na terenach alpejskich, jak zauważa Manfred Koller, ,znane z hiszpańskich figur prawdziwe włosy rozpowszechniły się już w późnogotyckich krucyfiksach, lecz pojawienie się szklanych oczu i malowanych części z wosku należy przypisać wpływom znad Morza Śródziemnego", co ułatwiały powiązania między habsburskimi terenami dziedzicznymi a królestwem Hiszpanii. Dzięki nim XVI-wieczna woskowa figurka Dzieciątka Jezus, słynne praskie Jęulatko, znalazła się jako prezent ślubny na terenach obecnych Czech.

23 M. Koller, Kleider, s. 19-58; idem, Polychromed sculpture and textile arts, ICOM committee for conservation, $11^{\text {th }}$ triennial meeting in Edinburgh, Scotland, 1-6 September 1996, preprints 1996, s. 410-415. Bliskie omawianej zdaje się wspomniane przedstawienie z Forchtenstein oraz z Heimingeberg w Tyrolu, zob. M. Koller, Kleider, s. 51.

24 Baza danych Institut royal du Patrimoine artistique w Brukseli: http://www. kikirpa.be/www2/cgi-bin/wwwopac.exe mieści ponad 1500 przykładów ubieranych rzeźb z terenu Belgii, większość z nich to przedstawienia Matki Boskiej z Dzieciątkiem, w przewadze XIX-wieczne, następnie XVII-XVIII-wieczne.

25 „Madonne” della „Laguna”: simulacri da vestire dei secoli XIV-XIX, ed. by R. Pagnozzato, Roma, Istituto della Enciclopedia italiana, Venezia, Regione del Veneto, Giunta regionale, 1993; Virgo gloriosa - Percorsi di conoscenza, restauro e tutela delle madonne vestite, Atti del Convegno organizzato in occasione di Restauro 2005 Salone dell'arte del Restauro e della Conservazione dei beni culturali e Ambientali, Ferrara, 9 aprile 2005 a cura di Lidia Bortolotti - dokument pdf na stronie: http:/ / online.ibc. regione.emilia-romagna.it/I/libri/pdf/virgo: C. Caneva, Dressed statuettes of the Ma- 
Niemiec ${ }^{26}$ o identycznym geście dłoni również skłania do takiej interpretacji. Stylistyka tego rodzaju dzieł, zwłaszcza tych bez modelowanych w drewnie partii szat, nie podlegała dramatycznym zmianom, co utrudnia precyzyjne datowanie, niemniej jednak prawidłowe zdaje się ustalenie dolnej cezury czasu wykonania rzeźby około połowy XVII wieku, najwcześniej na początku tego stulecia ${ }^{27}$.

Intrygujący jest otwór o wykroju serca wydrążony w korpusie Madonny. Skłania on do przypuszczeń, że opisywana rzeźba zalicza się ikonograficznie do przedstawień Maryi jako Vas Electionis, czyli „Naczynie Wybrane” czy „strażniczka hostii”" ${ }^{28}$. W Polsce znane sa przykłady barokowych monstrancji z XVII i XVIII wieku, obrazujących ten typ ikonograficzny będący typem przedstawienia Niepokalanej. Ukazywanie Maryi jako „Naczynia Wybranego”, z reservaculum umieszczonym w łonie, zdarzało się też w monstrancjach z wizerunkiem Matki Boskiej jako Mater Misericordiae z 1687 roku z kościoła Wszystkich Świętych w Gliwicach czy Mater Omnium z Iwanowic z 1826 roku $^{29}$. Wydaje się prawdopodobne, że wycięcie w korpusie opisywanej rzeźby mogło służyć jako reservaculum ${ }^{30}$.

Rzeźba Madonny funkcjonuje wraz z bardzo mała (wys. 9,3 cm) rzeźbą przedstawiającą Dzieciątko. Jest ono ukazane jako nagie niemowlę, w pozycji siedzącej (lub leżącej z nóżkami zgiętymi w kolanach). Jego

donna. E. Silvestrini, Corredi e dotazioni delle Madonne „da vestire”, „La Ricerca Folklorica, La devozione dei laici: Confraternite di Roma e del Lazio dal Medioevo ad oggi", 2005, vol. 52, s. 17 - zwraca uwagę, że we Włoszech są szczególnie rozpowszechnione przedstawienia simulacri da vestire Matki Boskiej Szkaplerznej, Różańcowej i Bolesnej, co znajduje potwierdzenie w dostępnych ilustracjach, niemniej odnaleziono kilka przykładów przedstawień Matki Boskiej z Dzieciątkiem trzymającej berło. Inne przykłady w: E. Silvestrini, G. Gri, R. Pagnozzato, Donne madonne dee: abito sacro e riti di vestizione, gioiello votivo, vestitrici: un itinerario antropologico in area lagunare veneta, Padova 2003.

26 Na przykład rzeźby z kościołów w Asbach, w Gaggers: http://www.kirchenundkapellen.de/kirchen.

27 Ustalenie poczynione w wyniku konsultacji z historykiem sztuki Sławomirem Majochem. Jego opracowanie rozwinie kwestie stylistyczne i ikonograficzne.

28 Ikonografia nowoṡytnej sztuki kościelnej w Polsce, t. 1, pod red. ks. J. Pasierba, Warszawa 1987, s. 90.

29 Ibidem, t. 2, s. 41.

30 Hipoteza wysunięta przez historyka sztuki Sławomira Majocha. 
główka jest zwrócona w lewo w stosunku do osi korpusu. Dziecko jest wyrzeźbione proporcjonalnie i poprawnie anatomicznie, ma twarz o pogodnym wyrazie, o pucołowatych policzkach, lekko uwypuklone oczy, mały nos, wyraźnie zaznaczone usta o lekko uniesionych kącikach. Jego ciało jest pulchne, z zaznaczonymi fałdkami na udach. Prawą rękę zgiętą w łokciu unosi w geście błogosławieństwa, lewa nie zachowała się, lecz zarys w miejscu jej oderwania dowodzi, że była ułożona bliżej tułowia. Gest błogosławiącej ręki wskazuje jednoznacznie na to, że rzeźba stanowi przedstawienie Dzieciątka Jezus. Jego poza sugeruje, że mogło ono od początku funkcjonować razem z jakimś wizerunkiem Madonny. Rzeźba jest wykonana z dużą biegłościa, precyzyjnie, na wysokim poziomie artystycznym. Jej forma pozwala zakładać, że powstała ona około połowy XVIII wieku. Wtórnie (już w XX wieku) wyposażono ją w plastikową rączkę lalki, o proporcjach odpowiadających wielkości figurki.

Wtórny element całego przedstawienia Madonny z Dzieciątkiem stanowi podstawa. Jest nią obecnie cokół bez wyraźnych cech stylowych o szerszym dolnym gzymsie i węższym górnym, z wklęsło opracowaną przestrzenią między nimi, ujętą od frontu w narożach w pary wolut $\mathrm{z}$ wolim okiem. Pomiędzy nimi znajduje się opracowany wypukle, rozmieszczony w dwóch rzędach napis: „MATER CHRISTI ORA PRO NOBIS”. Podstawa jest wewnątrz wydrążona, jej górna powierzchnia jest płaska. Opisany cokół zastępuje, najprawdopodobniej od lat 70. XX wieku (?), nieistniejąca pierwotna podstawę rzeźby, o nieznanym kształcie. Wtórne są także komplety szat, złożone $z$ ozdobnych spinanych z przodu płaszczy z kołnierzem sięgajacym tyłu korony i prostych sukni spodnich oraz jednowarstwowych sukienek Dzieciątka. Ubiory nie nawiązywały stylowo do żadnego z okresów historycznych (przykład - il. 1). Sukcesywnie przebierano $\mathrm{w}$ nie rzeźby, wielokrotnie w ciagu roku, upozowując ramiona Madonny i upinając szaty tak, by trzymała Dzieciątko przed sobą.

Peruka nakładana na głowę Madonny została wykonana z założeniem przysłonięcia jej górnej i przedniej części ubiorem (welonem-płaszczem, korona). Pasma włosów są zamocowane poniżej nieeksponowanego wierzchołka, gdzie można zauważyć siatkowy czerep. Sposób pierwotnego upięcia włosów nie jest czytelny, w późniejszym czasie zostały one skręcone z tyłu w niski kok (il. 4). Metalowa „złota” korona na głowie Maryi, dekorowana imitacjami kamieni ozdobnych - czerwonych, 
błękitnych, zielonych i bezbarwnych (rubinów, szafirów, chryzoprazu?, kryształu górskiego?) o diamentowym szlifie, jest wzorowana, w uproszczeniu, ale z zachowaniem charakterystycznego kształtu, na koronie rudolfińskiej, stanowiącej symbol dynastii Habsburgów. Obecna korona Dzieciątka jest wtórna, złota, nie nawiązuje do rudolfinskiej, ma kształt obręczy z osadzonymi w niej rubinowymi kamykami, z kabłąkowato wygiętymi prętami zwieńczonymi krzyżykiem.

\section{Budowa techniczna i technika wykonania oraz stan zachowania elementów przedstawienia}

\section{Metodyka badań}

We wstępnej fazie dokonano szczegółowych obserwacji rzeźb Madonny i Dzieciatka, rejestrując dane dotyczące ich budowy i stanu zachowania, pozwalające zrekonstruować na ich podstawie materialną historię obiektu. Konfrontowano uzyskane informacje $z$ dostępnymi w opracowaniach odnoszących się do innych simulacri da vestire ${ }^{31}$.

Budowę techniczną oraz technikę wykonania i użyte materiały określono na podstawie analizy obrazów uzyskanych w badaniach nieniszczących - rentgenowskich ${ }^{32}$ (il. 5), termowizyjnych ${ }^{33}$, w podczerwieni i we fluorescencji UV ${ }^{34}$ (il. 6) oraz na podstawie obserwacji układu warstw pod powiększeniem bezpośrednio na rzeźbach uzupełnionych instrumentalnymi badaniami pobranych próbek (przykłady: il. 7-10). Zidentyfikowano

31 M. Koller, Kleider, Virgo gloriosa.

32 Rentgenogramy i tomografię rentgenowską wykonano w Zakładzie Diagnostyki Obrazowej Wojewódzkiego Szpitala Zespolonego im. Ludwika Rydygiera w Toruniu; interpretacja otrzymanych obrazów: dr Elżbieta Szmit-Naud.

33 Rejestracja danych Sławomir Melkowski, Parametry kamery: producent FLIR, typ - P620, czułość termiczna $-<=65 \mathrm{mK}$, zakres widmowy $-7,5,13 \mathrm{~mm}$, typ detektora - jednorodna matryca niechłodzonych detektorów mikrobolometrycznych (FPA), rzeczywista liczba - pikseli w obrazie $\geq 640 \times 480$, interpretacja dr Jarosław Rogóż.

34 Fotografie wykonał Adam Cupa, interpretacja dr Jarosław Rogóż. 
gatunek drewna ${ }^{35}$. Z części próbek wykonano przekroje i obserwowano je w VIS i we fluorescencji UV, rejestrując otrzymany obraz na fotografiach (przykłady: il. 11-13). Obserwacje fluorescencji w UV dostarczyły wybiórczych specyficznych informacji o pigmentach i stanie oraz typie spoiw $^{36}$. Przekroje poddano także badaniom pod mikroskopem skaningowym SEM-EDS ${ }^{37}$, co służyło pośredniej identyfikacji pigmentów. $\mathrm{Na}$ przekrojach wykonano wstępne testy mikrochemiczne. Przeprowadzono analizy sproszkowanych próbek we fluorescencji rentgenowskiej (XRF) ${ }^{38}$, badania spoiw w podczerwieni FTIR-TR ${ }^{39}$, badania mikrochemiczne pigmentów i spoiw ${ }^{40}$, a dla oryginalnej warstwy malarskiej i warstw pierw-

35 Dr Marcin Koprowski, Pracownia Dendrochronologiczna, Instytut Ekologii i Ochrony Środowiska, Wydział Biologii i Nauk o Ziemi UMK, Toruń.

36 Fotografie mikroskopowe przekrojów próbek UV-VIS i interpretacja: dr Zuzanna Rozłucka w konsultacji z dr Elżbietą Szmit-Naud, Zakład Konserwacji Malarstwa i Rzeźby Polichromowanej IZK UMK, mikroskop Nikon Eclipse 600.

37 Dr Grzegorz Trykowski, Pracownia Analiz Instrumentalnych, Wydział Chemii UMK, Toruń, mikroskop elektronowy LEO 1430VP, LEO Electron Microscopy Ltd. Cambridge, England, z detektorem elektronów elastycznie odbitych (ang. backscattered electron - BSE), w trybie zmiennopróżniowym, $\mathrm{p}=50 \mathrm{~Pa}$, rozdzielczość 1-5 $\mu \mathrm{m}$, czułość $10^{-12} \mathrm{~g}$. Analiza EDS energodyspersyjnym spektrometrem rentgenowskim Quantax 200, produkcji Bruker-AXS Microanalysis GmbH, Berlin, Germany, z detektorem EDX XFlash 4010. Interpretacja wyników badań SEM-EDS w zestawieniu z badaniami mikroskopowymi przekrojów próbek - dr Elżbieta Szmit-Naud.

38 Adam Cupa, Zakład Technologii i Technik Malarskich, IZK UMK, Toruń, spektrometr rentgenowski MiniPal PW 4025.

39 Analizę wykonała Wiesława Topolska, Zakład Konserwacji Elementów i Detali Architektonicznych IZK UMK, Toruń. Widma absorpcyjne w podczerwieni rejestrowano za pomoca spektrometru fourierowskiego (FTIR) firmy Bruker z zastosowaniem techniki osłabionego całkowitego wewnętrznego odbicia (ATR - attenuated total reflectance) metoda jednoodbiciowa. Jako element odbiciowy wykorzystano pryzmat diamentowy. Próblki przeznaczone do badań miały postać sproszkowana, zajmowały pole o średnicy do 1,5 mm o grubości do $0,5 \mathrm{~mm}$ (?).Widma rejestrowano w zakresie od 400 do $4000 \mathrm{~cm}^{-1}$. Interpretacji dokonał dr Paweł Szroeder, Instytut Fizyki UMK, w konsultacji z dr Elżbietą Szmit-Naud.

40 Badania mikrochemiczne na przekrojach: dr Elżbieta Szmit-Naud, badania mikrochemiczne wypreparowanych pigmentów, spoiw, włókien: Elżbieta Orłowska. 
szych przemalowań - analizę chromatograficzną HPLC ${ }^{41}$. Najbardziej współczesnych materiałów nie identyfikowano instrumentalnie.

\section{Oryginalne opracowanie rzeźb}

\section{Rzeźba Madonny}

Rzeźbę wykonano z drewna lipowego, konstruując figurkę z kilku odrębnie wyciętych elementów połączonych ze sobą w sposób zapewniający ruchomość głowy i rąk (il. 3). Głowę i szyję wyrzeźbiono w kawałku drewna pochodzącym z partii oddalonej od rdzenia ${ }^{42}$. Korpus rzeźby wraz z nogami wycięto z jednego kawałka drewna, z partii przyrdzeniowej, jedynie pod wycięciem na stawy ramion montując wewnątrz małe drewniane podkładki. Dolną część rzeźby, tj. putto z obłokiem, wykonano osobno, najprawdopodobniej razem z niezachowaną dalszą częścią obłoku z tyłu i drugim puttem lub obłokiem od frontu rzeźby, pod lewym skrzydłem, w kawałku złożonym z dwóch sklejonych kloców o prostopadłym układzie włókien, i przed polichromowaniem połączono z pozostałymi elementami. Ramiona zostały wykonane w formie wydrążonych tulejek z panewką stawu barkowego, w której wycięto otwór na sznurek łączący ręce z tułowiem i głowa. Przedramiona są pełne, z dłońmi i palcami rzeźbionymi w jednym kawałku, z kulista, obrobioną dłutem panewką stawu łokciowego wchodząca w tulejkę ramienia. W panewkach wycięto wewnątrz rowki i przewiercono na wylot otwór do wierzchniej strony przedramion - na wspomniany sznurek. Dłutem został też wydrążony otwór w korpu-

41 Analizę wykonała i zinterpretowała dr Jana Debognie-Sanyova, Laboratoires de l'Institut rogal du Patrimoine artistique, Bruksela; High-performance liquid chromatography z UV-Vis Diode array detector (HPLC-DAD, Spetratech Finnigan z UV6000) po ekstrakcji barwników z próbki w mieszaninie: 4N HF / DMF / ACN 2/ /1/1 w temperaturze laboratorium, do odbarwienia.

${ }^{42}$ Informacje dotyczące cech anatomicznych podłoża rzeźb uzyskano dzięki wykonanym tomogramom. 
sie o zewnętrznym wykroju w kształcie serca ${ }^{43}$. Otwór ten jest skomunikowany z szyją i biegnie, zwężając się klinowato w dół, do wewnętrznej krawędzi lewej nogi aż do wysokości połowy łydki. Przypuszczalnie podczas rzeźbienia klocek drewna był osadzony na trzpieniu wetkniętym w ten otwór. Po wyjęciu go wewnętrzna strona lewego uda i łydki zostały uformowane z zanurzonego w kleju glutynowym bielonego płótna konopnego. Głowę wyrzeźbiono wraz z szyja po przedłużeniu kawałka drewna doklejonym plastrem drewna i zakończono na obwodzie uskokiem, tak by opierała się na krawędziach okragłego wycięcia w korpusie. Krawędzie obu elementów zostały docięte, żeby w idealnym dopasowaniu głowa figurki była skierowana lekko w lewo. Klatka piersiowa została opracowana płasko. Kosmyki włosów po bokach i z tyłu głowy wycięto niewielkim dłutem o trójkątnym przekroju. Następnie w głowie wydrążono otwór pozwalający połączyć ją, pierwotnie prawdopodobnie za pomocą sznurka, z barkami i przypuszczalnie umożliwiający stabilne zamocowanie korony.

Niewielkim płaskim dłutem opracowano detale palców dłoni i stóp (paznokcie) oraz pióra skrzydeł putta. Okragły otwór w lewym pośladku, powstały po usunięciu fragmentu rdzenia, został wypełniony flekiem. Powierzchnię rzeźby wygładzono - z wyłączeniem stawów, włosów oraz wnętrza otworu w korpusie i obwodu „serca”. Wnętrze „serca” zostało pokryte cienką warstwą farby roztwarzalnej w wodzie zawierającej czerwony barwnik organiczny.

Powierzchnię drewna przeklejono klejem glutynowym. Chuda zaprawę o barwie szarawobiałej, klejowo-kredowa, naniesiono na cała powierzchnię rzeźby w kilku warstwach, oszczędnie na panewkach stawów rak. Na przeznaczone do srebrzenia na poler partie skrzydeł putta i obłoku za nim został naniesiony czerwony pulment o barwie ciemnej czerwieni żelazowej (il. 12). Srebrzenie wykonano folia srebrna i po wypolerowaniu na skrzydła putta naniesiono laserunki z transparentnej farby olejnej zawierającej zieleń miedziową - na bokach skrzydeł (il. 10), lub czerwony lak - na pióra pod broda putta. Partie karnacyjne pokryto nierówno warstwą izolująca (rodzajem podmalowania?) barwy ciemnobrązowej,

43 Wielkość otworu: wysokość: 3,6-4,17 cm, szerokość 3,17 cm, wewnętrzne wydrążenie na głębokość $2,8 \mathrm{~cm}$ i $3,69 \mathrm{~cm}$ wszerz wskazuje, że jest możliwe użycie go jako reservaculum, mógł pomieścić hostię. 
w tłustym spoiwie, którym był najprawdopodobniej pokost. Duże napięcie powierzchniowe spowodowało, że już w momencie nałożenia izolacja nie przylegała dobrze, w wielu miejscach zbiegła się i zastygła w krople (il. 11).

Do polichromowania rzeźby użyto oszczędnej palety pigmentów składały się na nią: biel ołowiana, czerwień żelazowa, cynober, czerwień organiczna, brąz żelazowy - umbra oraz czerń organiczna, najprawdopodobniej roślinna. Spoiwo farb było tłuste temperowe, niejednorodne - modyfikowane zapewne już na palecie dodatkiem białka, na co wskazuje analiza spoiw próbek pobranych z różnych partii, być może także skrobi ${ }^{44}$. Karnacja, włączywszy wszystkie detale twarzy, została pokryta rozlewną farbą różową (obecnie wskutek zmian - ciemna, brunatnoróżowawa - il. 8,11), zawierająca czerwień żelazowa, biel ołowianą i czasem domieszkę cynobru i czerni, gładko i dosyć cienko. Następnie białka oczu pomalowano bielą i na niej zaznaczono jasnym chłodnym brązem tęczówki, a na nich czernią źrenice oczu ${ }^{45}$. Usta zostały pomalowane ciemna czerwoną farbą zawierającą czerwień żelazowa. Włosy pokryto ciemnym brązem z brązu żelazowego w odcieniu umbry palonej (il. 7, oznaczenie 1). Łuki brwi zostały prawdopodobnie pociagnięte tą sama farba (warstwy oryginalne w tej partii nie zachowały się). Wnętrze serca pokryto kolorem karnacyjnym (przy krawędziach), na który nałożono czerwienią składającą się z czerwieni żelazowej z niewielkim dodatkiem bieli ołowianej i domieszką cynobru, korygując tym samym wygląd pierwszej czerwonej warstwy, zapewne w dążeniu do nadania jej bardziej nasyconego i jednolitego kolorytu. $\mathrm{Na}$ twarzy putta wstępnie zaznaczono na zaprawie rumieńce na policzkach i brodzie, po czym pokryto warstwą karnacyjną w odcieniu różowym cieplejszym i jaśniejszym niż w przypadku karnacji Matki Boskiej (dziś różowożółtawym - barwa warstwy uległa zmianom), używając farby zawierającej biel ołowianą z czerwienią organiczną w tłustym spoiwie temperowym. Włosy putta zostały także pomalowane ciemnym brązem z dodatkiem umbry. Usta opracowano podobnie jak usta Madonny, oczy

44 Zidentyfikowanej jako jeden z możliwych składników spoiwa metodą FTIR, niepotwierdzony w innych badaniach.

45 Stratygrafię i barwę poszczególnych warstw określono in situ, w obserwacji przekroju na krawędzi spękania na prawym oku, pod mikroskopem. 
zapewne również. Ramion rzeźby nie polichromowano. Powierzchnię pokryto werniksem żywicznym, przypuszczalnie kalafoniowym.

\section{Rzeźba Dzieciątka}

Do wykonania figurki Dzieciątka Jezus użyto również drewna lipowego. Niemal cała postać wyrzeźbiono w jednym kawałku, jedynie lewą rączkę Dzieciątka sklejono z dwóch części, pionowo na ramieniu, powyżej łokcia. Rzeźbę wykonano z dbałością o detale anatomii, precyzyjnie, dłutem (ślady narzędzia są widoczne $z$ tyłu figurki), wygładzając powierzchnię. Z tyłu wycięto otwór o średnicy 1,5-2 mm ułatwiający osadzenie rzeźby do polichromowania. Powierzchnię drewna przeklejono klejem glutynowym i pokryto biała zaprawa złożona z kredy i bieli ołowianej w spoiwie najprawdopodobniej tłustym emulsyjnym, w warstwie niejednorodnej grubości. Do malowania rzeźbę zamocowano na cienkim trzpieniu osadzonym w małym otworze wydrążonym z tyłu. Do malowania karnacji użyto bardzo jasnej, różowej, tłustej farby temperowej zawierającej biel ołowianą i czerwień organiczną (wskutek zmian starzeniowych obecny odcień tej warstwy jest żółtaworóżowy) (il. 9, 13). Polichromia została wmalowana w świeżą jeszcze warstwę zaprawy. Usta Dzieciątka i dziurki nosa zostały podkreślone czerwienią w odcieniu czerwieni żelazowej. Białka oczu zaznaczono bielą. Włosy namalowano na kolorze karnacyjnym farbą jasnobrązowa.

\section{Stan zachowania elementów oryginalnych}

Forma rzeźbiarska oryginalnego przedstawienia jest w ogólnym kształcie zachowana, choć dłonie Madonny są pozbawione większości palców (z sześciu zachowały się tylko fragmenty, dwa są kompletne), lewa noga jest złamana poniżej kolana, brakuje przedniego fragmentu jej lewej stopy, obu pięt, fragmentu skrzydła putta, jego nosa, obłoku. Korpus rzeźby jest pęknięty od grzbietu lewego ramienia wzdłuż do zgięcia nogi pod kolanem. Inna cienka włosowata szczelina biegnie (przez wszystkie warstwy) z prawej strony twarzy Maryi i wzdłuż prawego policzka. Dzieciątko nie ma całej lewej ręki, a czubek jego nosa jest zmiażdżony. Część 
zniszczeń jest skutkiem przypadkowych urazów doznawanych w trakcie manipulowania rzeźbami (przebierania i noszenia: utrata palców, obtłuczenia), część to rezultat obróbki, jakiej poddano podstawę rzeźby, tj. elementy znajdujące się bezpośrednio pod stopami Madonny, zachowując tylko putto i fragmenty obłoku. Struktura drewna jest lokalnie nieznacznie naruszona przez owady - w dolnej partii: lewa noga w okolicach złamania, stopa, putto oraz w okolicach otworu wyciętego w korpusie, z lewej strony. Drewno, z którego wykonano rzeźbę, reaguje w widoczny sposób na zmianę warunków klimatycznych w otoczeniu. Płótno, z którego uformowano fragment lewej nogi, zachowało się w dobrym stanie.

Przeklejenie oraz spoiwo zaprawy na rzeźbie Madonny są częściowo zdegradowane, wskutek czego zaprawa utraciła elastyczność, obecnie jest krucha i silnie spękana, podobnie warstwa malarska. Adhezja warstwy malarskiej do zaprawy jest w wielu przypadkach osłabiona w wyniku błędu technologicznego - naniesienia przed malowaniem tłustej izolacji. Aktualna barwa tego malarskiego opracowania jest ciemna, co stanowi efekt zmian, które w nim zaszły (il. 8). Zachowane partie srebrzone na skrzydełkach putta, pokryte laserunkami, sa na znacznej powierzchni skorodowane, mają słabą adhezję do pulmentu. Warstwy laserunków są kruche, ale silnie zespolone z pozostałościami srebra (il. 10).

Pierwsze zniszczenia oryginalnej polichromii, związane z lokalna całkowitą utratą adhezji do drewna - np. w partii twarzy, pleców, okolic złamania lewej nogi, fragmentów skrzydełek putta - nastąpiły już dość wcześnie, prawdopodobnie wówczas, gdy rzeźbę przechowywano w niesprzyjających warunkach ${ }^{46}$. Warstwy oryginalnej zaprawy i polichromii na postaci Dzieciątka są zniszczone - zredukowane w swojej grubości - zapewne w celu przygotowania do naniesienia przemalowania, stanowiącego pierwszą wspólną polichromię obu postaci (il. 9, 13).

46 Informacje o warunkach przechowywania zob. podrozdział „Pochodzenie i dzieje rzeźby..." niniejszego artykułu. 


\section{Wtórne opracowania polichromii i inne wtórne elementy z XVIII wieku}

Rzeźbę Madonny poddano pierwszym zabiegom „renowacyjnym” najprawdopodobniej wówczas, gdy znalazła się ona w posiadaniu księżnej, na początku XVIII wieku. Wydaje się możliwe, że mogło to nastąić przed poświęceniem przedstawienia (tj. przed 1727 rokiem), kiedy przygotowywano je do tego wydarzenia. Konieczna była naprawa lewej nogi złamanej na wysokości łydki, w której, po powiększeniu otworu wewnątrz, umieszczono trzpień z drewna iglastego łączący obie części nogi i - stosując jako spoiwo klej glutynowy - wklejono uzupełniający flek, od połowy łydki do kostki. Prawa noga poniżej łydki też nosi ślady naprawy.

Szczegółowa analiza obiektu i pobranych próbek doprowadziła do wniosku, że oryginalne opracowanie malarskie twarzy rzeźby musiało już wówczas być w złym stanie, gdyż pokryto ją nową zaprawą bezpośrednio na drewnie. Po przeklejeniu w grubej warstwie naniesiono zaprawę na szyję i barki rzeźby, łącząc za jej pomocą tors z głowa, co widocznie zniekształciło pierwotną formę i spowodowało unieruchomienie głowy (il. 3, $5,7,8)$. W grubej warstwie zaprawy, roztartej coraz cieniej do talii, został uformowany nowy kształt klatki piersiowej. Cienką warstwa pokryto plecy rzeźby, także częściowo pozbawione warstw oryginalnych, przedramiona, dłonie, reperowany fragment lewego podudzia i stopy. Zaprawę tworzyła biel ołowiana z kredą w spoiwie emulsyjnym. Dno otworu w korpusie zasklepiono barwiona pigmentami masa woskowa. Cała powierzchnię przedstawienia pokryto przemalowaniem. Karnację Matki Boskiej z wyjątkiem ramion, karnację putta oraz Dzieciątka pomalowano farbą złożona głównie $z$ bieli ołowianej z dodatkiem pigmentów żelazowych: czerwieni żelazowej, ugru, w spoiwie olejnym (przypuszczalnie zawierającym pokost), w jednej lub kilku cienkich warstwach (il. 11 i 13). Ramiona (tulejki) pociagnięto wyłącznie spoiwem lub bardzo rozrzedzoną farbą. Oczy Madonny pomalowano brązem bezpośrednio na zaprawie, usta czerwienią zawierająca cynober, wnętrze „serca” także czerwoną warstwą z cynobrem. Włosy Madonny zostały pokryte jaśniejszym brązem, miejscowo bezpośrednio na odsłoniętym drewnie, włosy putta podobną farba, włosy Dzieciątka farbą brązową zawierająca pigment brązowy i czarny. 
Z okresu opisywanych interwencji pochodziły najprawdopodobniej korony: zachowana korona Madonny - pozłacana, wysadzana imitacjami kamieni, oraz znana $\mathrm{z}$ fotografii $\mathrm{z}$ drugiej połowy XX wieku korona Dzieciątka, która miała uproszczoną formę zbliżoną do rudolfińskiej korony Madonny, bez kamieni. Szaty i inne elementy stroju rzeźb z tego okresu nie zachowały się. Niewykluczone, że część szat wymieniana w inwentarzu z 1827 roku pochodziła jeszcze z XVIII wieku.

W niedługim czasie po opisanych zabiegach bezpośrednio na pierwsze przemalowanie zostało naniesione kolejne, co mogło nastapić w drugiej połowie XVIII wieku, po zmianie właściciela rzeźby (po przewiezieniu jej na Śląsk?). W partiach karnacji przemalowanie miało niemal identyczny wygląd jak poprzednie, lecz zawierało większą ilość bieli, lokalnie także czerwieni. Nałożono je najczęściej w kilku warstwach, być może w celu rozjaśnienia ciemniejącego pierwszego przemalowania. Karnacji Dzieciątka nie przemalowywano gruntownie, prawdopodobnie nie przemalowano też jego włosów. Twarz rzeźby Matki Boskiej tym razem pokryto kolorem karnacyjnym, włącznie z białkami oczu. Tęczówki zaznaczono brązem o rudawym odcieniu, źrenice ciemniejszym brązem. Przemalowano cienką warstwa karnację putta. Jego skrzydła zostały pokryte farbą zawierajacą sproszkowaną folię „złotą" (mosiężną i miedziana) w tłustym spoiwie temperowym (przypuszczalnie z powodu złej adhezji do metalowej folii nie stosowano tu spoiwa wyłącznie olejnego). Obłok pokryto cienką warstwą szarego błękitu z indyga z czernią i biela zmieszanego ze sproszkowaną folią srebrną lub, lokalnie, warstwą jasnego ugru (il. 12).

\section{Stan zachowania elementów XVIII-wiecznych}

Wtórna zaprawa ma dobra spoistość i przyczepność do warstw oryginalnych; w wyniku starzenia bardzo stwardniała. W miejscach, gdzie została grubo naniesiona, jest głęboko spękana. Obie warstwy pierwszych przemalowań karnacji stały się bardzo kruche, ale zachowały dobrą kohezję. Na czole i skroniach rzeźby Madonny i na czole Dzieciątka warstwy zostały mechanicznie starte wskutek manipulacji koronami ${ }^{47}$. Lokalnie uległy

47 Korona Madonny ma otok uformowany oryginalnie w owal, tak by tylko opierała się na czubku głowy. Ponieważ utrzymanie jej na głowie Madonny przy za- 
odspojeniu od wtórnej zaprawy i osypaniu - na twarzy, w dolnej partii tułowia. Pojedyncze ubytki maja postać wykruszeń o małej powierzchni. Spękania i odspojenia powstały na barkach i szyi rzeźby Madonny. Warstwy malarskie obu pierwszych przemalowań już w XIX wieku przybrały odcień, jaki prezentują obecnie, tj. ciemnobeżowy, szarawy (w odkrytych partiach wręcz jasnobrązowy lub brązoworóżowy, brudnawy - il. 3, 7, 8), co stało się zapewne powodem kolejnej interwencji.

\section{Warstwy i elementy XIX-wieczne}

Kolejne naprawy i „odświeżanie” obu rzeźb przeprowadzono już w XIX wieku, najprawdopodobniej w związku z ożywieniem kultu Matki Boskiej Zbrosławickiej około połowy wieku, co pośrednio potwierdza obecność bieli cynkowej w warstwach przemalowann ${ }^{48}$ (il. 11-13). Ponownie sklejono lewą nogę Madonny w miejscu poprzedniego złamania. Zapewne w tym czasie wymieniono też ele menty decydujące o ruchomości rąk Maryi. Po poszerzeniu otworu w głowie umieszczono w niej trzpień $\mathrm{w}$ formie klinowatej obręczy z paska stalowej blachy, unieruchamiając go nałożonym w poprzek paskiem blachy skręconym $z$ nią śrubą (widoczną na il. 5). Zamocowana w nim długa śruba dociska powstały „krzyżak”, blokując czop w otworze. Elementy te prawdopodobnie służą dociążeniu głowy - zostały do nich dołączone sznurki poprowadzone do rąk figurki, bawełniane, o grubości około $4 \mathrm{~mm}$, zawiązane na supeł na zewnątrz otworów w przedramionach. Ruch lewego przedramienia, którego sznurek jest poprowadzony we wnętrzu rzeźby wyżej niż ramienia prawego ${ }^{49}$, jest wyraźnie zależny od pozycji głowy.

W miejscach, gdzie nastapiło pęknięcie poprzednich uzupełnień, w okolicach szyi i barków, naniesiono warstwę zaprawy z kredy ze spoiwem prawdopodobnie emulsyjnym. Przemalowanie dotyczyło tylko tych partii rzeźby Madonny, które mogły być całkowicie bądź częściowo wi-

łożeniu w sposób prawidłowy sprawiało trudność, nasuwano ją, obracając pod kątem $90^{\circ}$ do właściwej osi, powodując zdzieranie warstw polichromii.

48 Stosowanej w malarstwie powszechnie od 1850 r., produkowanej na potrzeby wytwarzania farb od lat 40. XIX w.

49 Analizowano na tomogramach rzeźby. 
doczne - głowy, klatki piersiowej, barków, dłoni i przedramion, nóg, putta i obłoku. Rzeźbę Dzieciątka przemalowano w całości (il. 3). Była ona już pozbawiona całej lewej ręki - nie rekonstruowano jej wówczas.

Pierwsza podkładowa warstwa kremowej barwy wyrównywała powierzchnię i rozjaśniała koloryt przemalowywanych stref. Składała się głównie z bieli cynkowej z nieznaczną domieszką ugru w tłustym olejnym spoiwie, modyfikowanym bliżej nieokreślonym dodatkiem. Właściwe przemalowanie nałożono, wychodząc nieco w partiach karnacji poza strefy przykryte podkładem, czego efektem jest sinawy koloryt tych miejsc (il. 3). Podstawowe komponenty użytej farby to: biel cynkowa $z$ dodatkiem bieli ołowianej, pigmentów żelazowych (ugry, czerwień) i tłustego spoiwa temperowego (il. 11, 13), dzięki czemu miała ona gęstą konsystencję, co decydowało o jej małej rozlewności. Malowano pędzlem pozostawiającym wyraźny dukt, szeroki nawet do $10 \mathrm{~mm}$, nadający powierzchni wyraźna reliefowa fakturę i niedbały wygląd (il. 7, 9,10 - oznaczenie 4). Detale oczy, usta, modelunek policzków, stóp - zostały wykonane poprawnie, lecz bez dbałości o precyzję, sztywnym pędzlem. Usta postaci i dziurki nozdrzy Matki Boskiej oraz putta pomalowano czerwienią żelazową z biela ołowiana. Podobna czerwienia podkreślono kąciki ich oczu i fragmenty górnej powieki. Brązem z bieli ołowianej z umbra i dodatkiem czerni namalowano brwi, linię górnej powieki jej lewego oka, tęczówki oczu putta, włosy Madonny i Dzieciątka. Malując włosy putta, dodano ugru, nie zaznaczono jego brwi. Brwi Dzieciątka namalowano szerokim pociagnięciem, lecz oczy potraktowano w sposób uproszczony, nanosząc tylko na kolor karnacyjny ciemnobrązowe plamki. Tęczówki oczu Madonny zostały namalowane po zaznaczeniu bielą białek błękitem z bieli ołowianej z ultramaryna, źrenice, podobnie jak źrenice oczu putta, podkreślono nieregularnie czernią węglowa (il. 7). Skrzydła putta zostały pokryte warstwa jasnoszara - z bieli ołowianej i cynkowej z czernią roślinna - oraz szarawym różem - powstałym przez dodanie czerwieni żelazowej. Obłok za puttem został pomalowany ciemniejszą błękitnawą szarością, złożona z bieli cynkowej z dodatkiem ultramaryny, czerwieni żelazowej i czerni roślinnej (il. 12).

Po przemalowaniu rzeźby na głowie Madonny zamocowano perukę, przyklejając ja grubą warstwą kleju glutynowego. Brakuje przesłanek pozwalających stwierdzić, czy sama peruka wykonana techniką klasycz- 
ną $a^{50}$ powstała na tym etapie, czy wcześniej. Składała się z około 20-centymetrowych tresek grubych, nieznacznie falujących włosów w odcieniu jasnoszatynowym, zamocowanych na jedwabnej nici i przyszytych w pięciu rzędach do czerepu z ciemnobrazowej siatki wzmocnionej na obwodzie i na krzyż rudą satynową taśmą (il. 4). Do górnej (wierzchniej) części peruki nie przyszyto tresek, zakładając, że będzie ona zasłonięta nakryciem głowy. W głowę rzeźby Matki Boskiej wbito stalowe gwoździe, po to by stabilniej przymocować perukę (ich lokalizacja wyklucza, że służyły one do podtrzymywania korony).

\section{Stan zachowania elementów XIX-wiecznych}

Warstwy jasnoróżowego przemalowania stały się kruche, zachowały dobra adhezję do siebie i do wtórnej zaprawy, lecz nie do poprzednich przemalowań - wskutek skurczu uległy lokalnie niewielkim odspojeniom i złuszczeniem, odsłaniając warstwy spodnie - na twarzy (il. 3, 7), włosach, klatce piersiowej, dolnej części lewej nogi rzeźby Madonny ${ }^{51}$, na postaci Dzieciątka. Na większych połaciach - pleców, szyi (il. 8), stóp, nad kolanem i na udzie lewej nogi, na krawędzi pęknięcia - powstały rozległe ubytki wszystkich warstw, które pokrywały rzeźbę Madonny z powodu pracy podłoża, jak i urazów mechanicznych, m.in. podczas przebierania rzeźby. Powierzchnia zachowanych przemalowań była trwale zabrudzona. Utrzymywanie rzeźby w stelażu (patrz poniżej) spowodowało otarcia i drobne ubytki.

Peruka jest zachowana częściowo. Jej elementy tekstylne są w dobrym stanie, jedynie nitki jasnobrązowej taśmy są lokalnie przedarte wskutek utlenienia włókien. Struktura samych włosów jest silnie osłabiona. Część pasm uległa wyłamaniu przy samej nasadzie peruki, inne złamały się w miejscach zagięć fryzury, co sprawiało wrażenie ich obcięcia, jedynie kilka pasm z prawej strony z tyłu i z lewej z boku zachowało swoja pierwotną długość (zob. il. 4 i 16). Włosy były silnie zabrudzone, zwłaszcza

50 F.-A. de Garsault, Art du perruquier, contenant la façon de la barbe; la coupe des cheveux; la construction des perruques d'bommes et de femmes; le perruquier en vieux; le baigneurétuviste, Genève: Slatkine reprints 1984 (reprint z Description des arts et métiers, Guérin 1767-1771); A. M. Sutton, Boardwork or the Art of Wigmaking, Etc: A Technical Handbook, Chicago 2003, reprint z $1921 \mathrm{r}$.

51 Wskutek naklejenia zabezpieczenia z taśmy klejącej. 
w partii nieosłoniętej korona, kurzem oklejonym na ich powierzchni - być może wskutek spryskania wtórnie powierzchni peruki jakimś nabłyszczającym środkiem kosmetycznym (lakierem do włosów?). Pierwotną barwę zachowały włosy we fragmencie peruki osłoniętym korona, partie odkryte wypłowiały, najsilniej z lewej strony i z prawej z przodu. Gwoździe wbite w głowę rzeźby Madonny są powierzchniowo skorodowane.

\section{Warstwy i elementy XX-wieczne}

Interwencje o charakterze naprawczym i lokalnym dokonywane w XX wieku następowały w różnym czasie. Przypuszczalnie w okresie ożywienia kultu po publikacji z 1926 roku przeprowadzono częściowe „odświeżenie": w miejscach uszkodzeń, powodowanych nakładaniem korony, i na przedramieniu oraz barkach rzeźby Madonny wykonano przemalowania kremowobeżową farbą olejną o ziarnistej strukturze (składu nie badano) (il. 3, 7, oznaczenie 5). Do rekonstrukcji lewej ręki Dzieciątka użyto plastikowej ręki lalki, łącząc ją z korpusem za pomocą kleju glutynowego (il. 3).

W późniejszym czasie (w latach 70.?) dolna partię rzeźby przymocowano do lipowego klocka z trzpieniem, służącym do mocowania w nowej podstawie. Putto, fragmenty obłoku, lewą stopę (przy użyciu drewnianych podkładek) przyklejono do klocka klejem glutynowym. Nowa podstawę - cokół rzeźby - wycięto z przyrdzeniowej partii liściastego drewna, najprawdopodobniej lipowego, obrobiono dłutem, wydrążając wnętrze, pokryto złoconą dekoracja, jedynie w partii napisu i wolut wykonaną złotem na zaprawie i pulmencie, w pozostałych partiach szlagmetalem na mikstion i brąza bezpośrednio na drewnie. Sporządzono mosiężną obejmę podtrzymującą rzeźbę Madonny w pasie, mocowaną za pomocą drutów i śrub do cokołu, by ustabilizować rzeźbę podczas jej noszenia. Obejmę oklejono plastrem lekarskim (il. 2). Podklejono złamanie lewej nogi klejem typu butapren i wypełniono nim luki pod stopami. Oklejono również uszkodzoną część nogi taśmą klejąca.

W późniejszym czasie uzupełniono w drewnie lipowym palce dłoni w rzeźbie Madonny ${ }^{52}$, część lewej stopy i przyklejono klejem typu wikol.

52 Prawdopodobnie w latach 90. przez jednego z parafian - informacja uzyskana od ks. Romualda Kokoszki. 
Uzupełnień nie polichromowano. Do elementów dodanych w XX wieku należą także nowe komplety szat, składające się ze spinanych z przodu płaszczy z kołnierzem i szat spodnich - sukni, stanowiących jedną całość, w przypadku szat Madonny zakładanych przez głowę, co wiązało się z koniecznością manipulowania rękoma rzeźby.

\section{Stan zachowania elementów XX-wiecznych}

Lokalne ostatnie przemalowania sa poszarzałe, kruche i choć mają dobra przyczepność do warstw spodnich, na czole rzeźby Matki Boskiej są częściowo przetarte wskutek manipulowania koroną. Tworzywo sztuczne rączki lalki, która posłużyła za rączkę Dzieciątka, było kruche i pęknięte. Klej z taśmy klejącej, użytej do zabezpieczenia pękniętej lewej nogi rzeźby, częściowo odspoił się od nośnika i wmigrował w strukturę warstwy malarskiej przemalowania, do której przylegał, trwale ją osłabiając. Trzy z ośmiu dosztukowanych palców dłoni Madonny odkleiły się (il. 3).

Złocenia na napisie postumentu zostały zmyte wskutek niefachowego czyszczenia, powierzchnia złoceń wykonanych szlagmetalem była pokryta zielonkawobrunatnym nalotem korozji, partie pomalowane brąza skorodowały zupełnie. Pozostałe wtórne XX-wieczne elementy są w dobrym stanie.

\section{Problematyka i założenia podjętej konserwacji i restauracji}

Podstawowym zadaniem było powstrzymanie postępu degradacji obu rzeźb - zamierzano je zrealizować, stosując zabiegi konserwatorskie i poprawiając warunki przechowywania rzeźb oraz sposób ich eksponowania. W tym celu przeanalizowano warunki klimatyczne i oświetleniowe w miejscu przechowywania zabytku oraz skonsultowano się w sprawie manipulowania rzeźbami z powodu zwyczajowego przebierania ich w różnych okresach liturgicznych.

Funkcja kultowa, którą pełni obiekt, skłoniła do podjęcia oprócz działań wyłącznie konserwatorskich także restauracji, polegającej na takim uzupełnieniu ubytków formy rzeźbiarskiej i polichromii, by oba przedsta- 
wienia - Matki Boskiej i Dzieciątka - odzyskały estetyczny i godny wygląd.

Stan oryginalnego opracowania malarskiego, zachowanego na najwyżej $50 \%$ aktualnej powierzchni rzeźby, trwale przebarwionego i niekorespondującego z pierwszą polichromią rzeźby Dzieciątka, niestety nie pozwalał na przywrócenie pierwotnej polichromii. Pierwsza i druga wspólna polichromia obu figur, silnie ze sobą związane i zachowane na około $60 \%$ powierzchni rzeźb, z założenia i w odróżnieniu od kolejnego przemalowania pokrywające je w całości i przewyższające je jakością wykonania, pierwotnie były brane pod uwagę jako nadające się do ekspozycji. Oranżowa fluorescencja w UV odsłoniętych powierzchni tych warstw nasuwała przypuszczenie, że ich ciemne zabarwienie jest rezultatem pokrycia warstwą lakieru szelakowego lub kalafoniowego, który uległ zmianom barwnym w procesie starzenia (il. 6,11). Obserwacje i testy przeprowadzone in situ oraz dalsze badania stratygrafii i instrumentalne badania składu warstw wykluczyły te hipotezę ${ }^{53}$. Ciemne zabarwienie wynika ze składu samych warstw malarskich, choć zidentyfikowane w nich pigmenty nie wskazują na taką przyczynę brązowawej kolorystyki ${ }^{54}$. Podjęte próby określenia powodu ciemnego, brązowego zabarwienia tych warstw malarskich (w odcieniu sjeny naturalnej lub szarawym beżoworóżowym) miały na celu orzeczenie, czy możliwe jest odtworzenie ich właściwej, tj. zamierzonej, barwy. Podejrzewano, że za zbrązowienie warstw w całej masie może odpowiadać obecność nietrwałego pigmentu organicznego, którego barwa uległa zmianie do brunatnej tonacji (np. czerwień lakowa indyjska Keria lacca czy czerwony barwnik z drzewa brazylijskiego, mniej trwałe od marzanny farbiarskiej). Obserwacje przekrojów w UV-VIS nie pozwoliły na jednoznaczne określenie ich zawartości, a analiza chromatograficzna próbek zawierających warstwy ciemnego przemalowania i warstwę oryginalną nie wykazała frakcji charakterystycznych

53 Analizy FTIR.

54 Metodami mikrochemicznymi oraz UV-VIS, FTIR (barwniki). Przed wykonaniem szczegółowych badań podejrzewano, że zamiarem wykonawcy polichromii było stworzenie wizerunku w typie „czarnych Madonn”, do czego mogło skłaniać zabarwienie pierwotnej karnacji, być może już ciemne w momencie przemalowywania, jednak nieobecność pigmentów mogących nadawać ciemną barwę tym warstwom przemalowań wykluczyła tę możliwość. 
dla tych barwników ani dla produktów ich rozkładu. Nie można jednak wykluczyć, że występują one w badanej warstwie malarskiej w tak małej ilości, że identyfikacja jest niewykonalna, niemniej wówczas niemożliwy byłby także ich dominujący wpływ na kolorystykę warstw malarskich ${ }^{55}$. Zestawione wyniki badań ${ }^{56}$ pozwalają sądzić, że ciemna barwa karnacji, zarówno oryginalnej, jak i późniejszych przemalowań, została uwarunkowana rodzajem spoiwa, którym najprawdopodobniej jest, w przeważającej ilości, sykatywowany olej, zapewne gotowany ze związkami ołowiu. Za fluorescencję mogą w tym przypadku odpowiadać mydła ołowiane zawarte w samym spoiwie ${ }^{57}$, a za ciemną barwę - samo spoiwo, które już w momencie użycia może być bardzo ciemne i ma tendencję do ciemnienia pod wpływem siarkowodoru z atmosfery. Obserwacje potwierdziły trwała skłonność warstw pierwszych przemalowań do ciemnienia po odsłonięciu ${ }^{58}$.

W tej sytuacji eksponowanie zmienionej tonalnie polichromii uznano za bezzasadne i jako właściwe rozwiązanie przyjęto usunięcie jedynie XX-wiecznych nawarstwień i pozostawienie XIX-wiecznego częściowego przemalowania rzeźb, mimo mankamentów jego wykonania, oraz restaurację tego opracowania, jak i polichromii XVIII-wiecznych, widocznych w partiach, których ono nie pokrywa. Ponadto, by uszanować historyczną wartość oryginalnego opracowania rzeźby Matki Boskiej, zdecydowano się pozostawić czytelne odsłonięte pozostałości w partii pleców i szyi z tyłu oraz włosów, karnacji skrzydeł putta, a zarazem przywrócić rzeźbie

55 Stwierdzono ponadto, że brązowawa barwa karnacji jest niezależna od tego, czy były to partie osłonięte, czy nie, nie ma wyraźnego zróżnicowania spowodowanego działaniem światła, co powinno nastąpić, jeśli tonację nadawałby karnacji nietrwały pigment organiczny. Skład atomowy warstw badany na przekrojach SEM-EDS nie pozwalał też jednoznacznie wskazać obecności substratów, na których są osadzane pigmenty organiczne.

56 Badań mikrochemicznych na przekrojach, na wyizolowanych próbkach i badań warstw FTIR ATR w zestawieniu z obserwacjami fluorescencji na powierzchni i na przekrojach oraz badaniami chromatograficznymi wykluczającymi obecność barwników.

57 Sugestia wyrażona przez dr Janę Debognie-Sanyova.

58 Potwierdzoną na warstwie malarskiej widocznej w ubytku i wykonanej w późniejszym czasie odkrywce. 
jej pierwotny charakter simulacrum o ruchomych członkach - usuwając nawarstwienia unieruchamiające głowę.

W ogólnym wyrazie przedstawienia, opierając się na przeprowadzonych badaniach samej rzeźby i analizie stylistycznej istniejących do dziś podobnych simulacri da vestire, postanowiono powrócić do wyglądu figur, na jaki wskazywały układ zachowanych fragmentów palców dłoni Maryi, upozowanie postaci Dzieciątka oraz fakt zamocowania na głowie Matki Boskiej korony, czyli królewskie przedstawienie Matki Boskiej - w koronie i z berłem oraz z Dzieciątkiem trzymającym w dłoni jabłko królewskie. Te założenia zostały zrealizowane w toku zabiegów konserwatorskich i restauratorskich, przeprowadzonych standardowymi metodami ${ }^{59}$. Dokonano rekonstrukcji brakujących palców dłoni Madonny, lewej ręki Dzieciątka oraz innych pomniejszych ubytków formy rzeźbiarskiej, a także korekt uzupełnień w dolnej partii rzeźby - w obrębie uszkodzonej lewej nogi Madonny, putta i mocowania w postumencie. Berło i jabłko królewskie wykonano w drewnie lipowym i pozłocono na poler, inspirując się w kształtach i proporcjach dokumentacja fotograficzna podobnych przedstawień ${ }^{60}$. Ubytki warstw malarskich uzupełniono pigmentami mieszanymi z roztworem $\mathrm{Pa}$ raloidu B-72, kierując się wysoką trwałością tego typu wypełnień i biorąc pod uwagę warunki, w jakich rzeźba będzie eksponowana (il. 14, 15, 17). Niestandardowe zadanie stanowiła konserwacja i restauracja peruki z naturalnych włosów. Po jej oczyszczeniu uzupełniono w sposób odwracalny pasma włosów (il. 16). Dokonano konserwacji i restauracji XX-wiecznego cokołu rzeźby.

Związane z funkcją kultową okresowe, wielokrotne w ciagu roku, zmiany szat Matki Boskiej, nawet przy założeniu absolutnej delikatności w manipulowaniu figurka podczas tych zabiegów, stanowiły istotny czynnik niszczący. W tej sytuacji, w celu zredukowania ryzyka uszkodzeń, konieczne było przyjęcie nowej zasady postępowania eliminującej przebieranie rzeźb na rzecz ekspozycji ich w stałym stroju, co zostało usankcjonowane decyzją kurii biskupiej. Nowy strój został wykonany stosownie

59 Prace konserwatorskie i restauratorskie zostały wykonane przez autorkę tego opracowania.

${ }^{60}$ Rekonstrukcję tych elementów i palców dłoni Madonny wykonała konserwator dzieł sztuki Anna Reiter. 
do typu przedstawienia - nawiązywał do istniejących przykładów takich strojów z epoki, głównie XVIII-wiecznych (il. 18). Poszczególne części stroju nakładano na rzeźby i dopiero na nich łączono je w całość, co gwarantowało bardzo ograniczoną manipulację samymi figurami. Opierając się na tych zasadach, wykonano nowe szaty przedstawienia Matki Boskiej Zbrosławickiej ${ }^{11}$ (il. 19). Koronę umocowano na czubku głowy Madonny, na welonie-płaszczu nałożonym na perukę, wykorzystując do mocowania otwór wycięty już pierwotnie w tym celu w głowie rzeźby. Ze względów bezpieczeństwa zachowano stelaż utrzymujący obiekt na cokole, jednak odizolowano go od bezpośredniego kontaktu z materią samej rzeźby.

Rzeźba została ponownie umieszczona w zwieńczeniu ołtarza, w miejscu, w którym znajdowała się przed konserwacją. Zostało ono wyposażone $\mathrm{w}$ nowe oświetlenie, o widmie pozbawionym UV i IR, niepowodujące przegrzewania otoczenia rzeźby i mniej intensywne, konieczne z powodu niskiej odporności na działanie światła niektórych materiałów (włosy, jedwab płaszcza, inne tkaniny) i umożliwiające regulację natężenia od 50 do 200 luksów.

${ }^{61}$ Projekt szat, haftu Mariogramu - autorka opracowania, wykonanie - G. Bryczek. Projekt i wykonanie haftu płaszcza Madonny - L. Tymińska. 


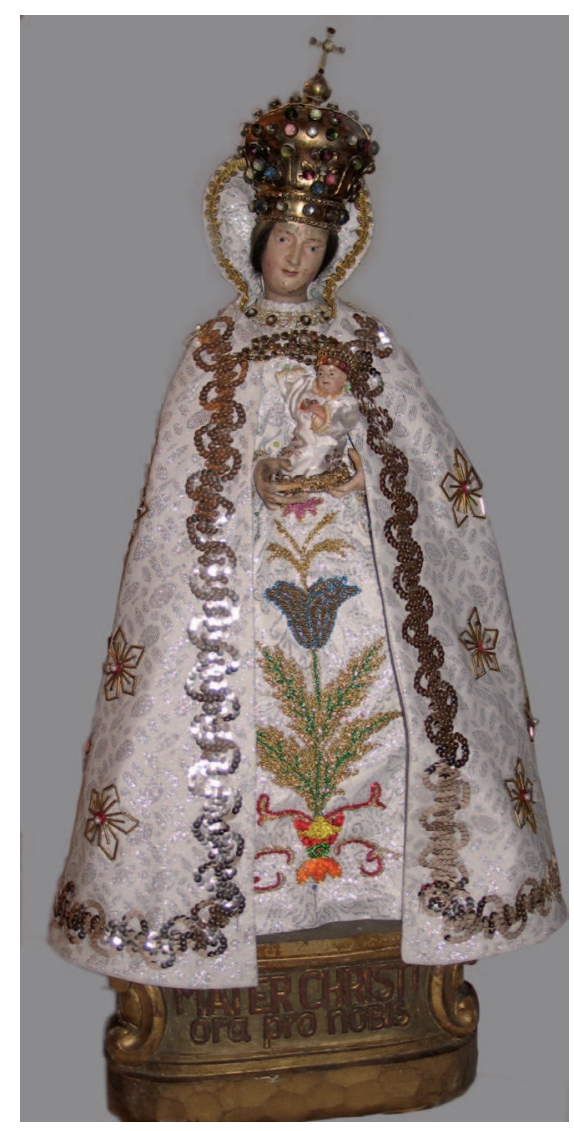

Il. 1. Matka Boska z Dzieciątkiem przed konserwacją w szatach z drugiej poł. XX w. (fot. A. Szadkowska)

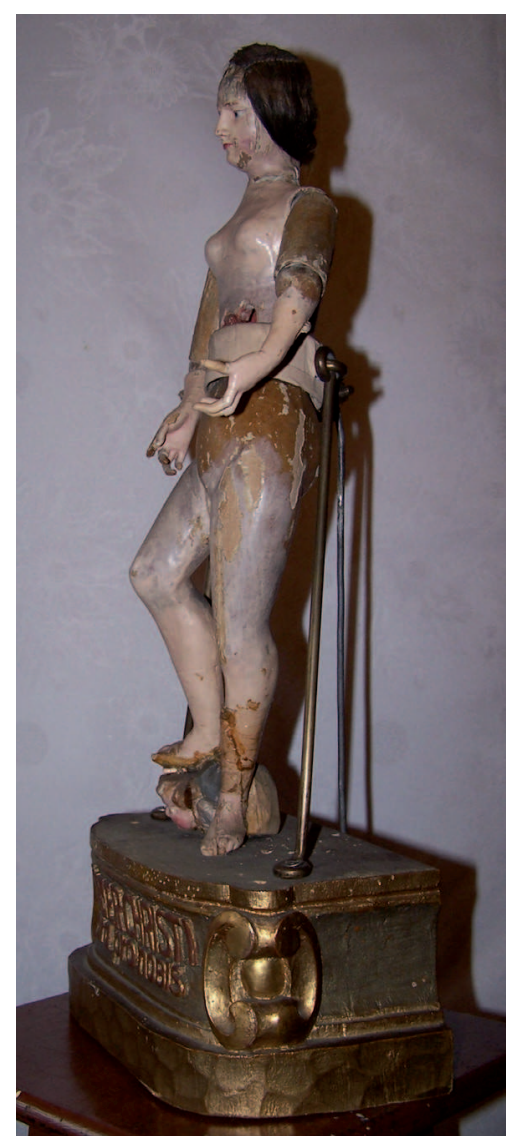

Il. 2. Rzeźba Madonny po zdjęciu szat, zamocowana na wtórnym cokole (fot A. Szadkowska) 


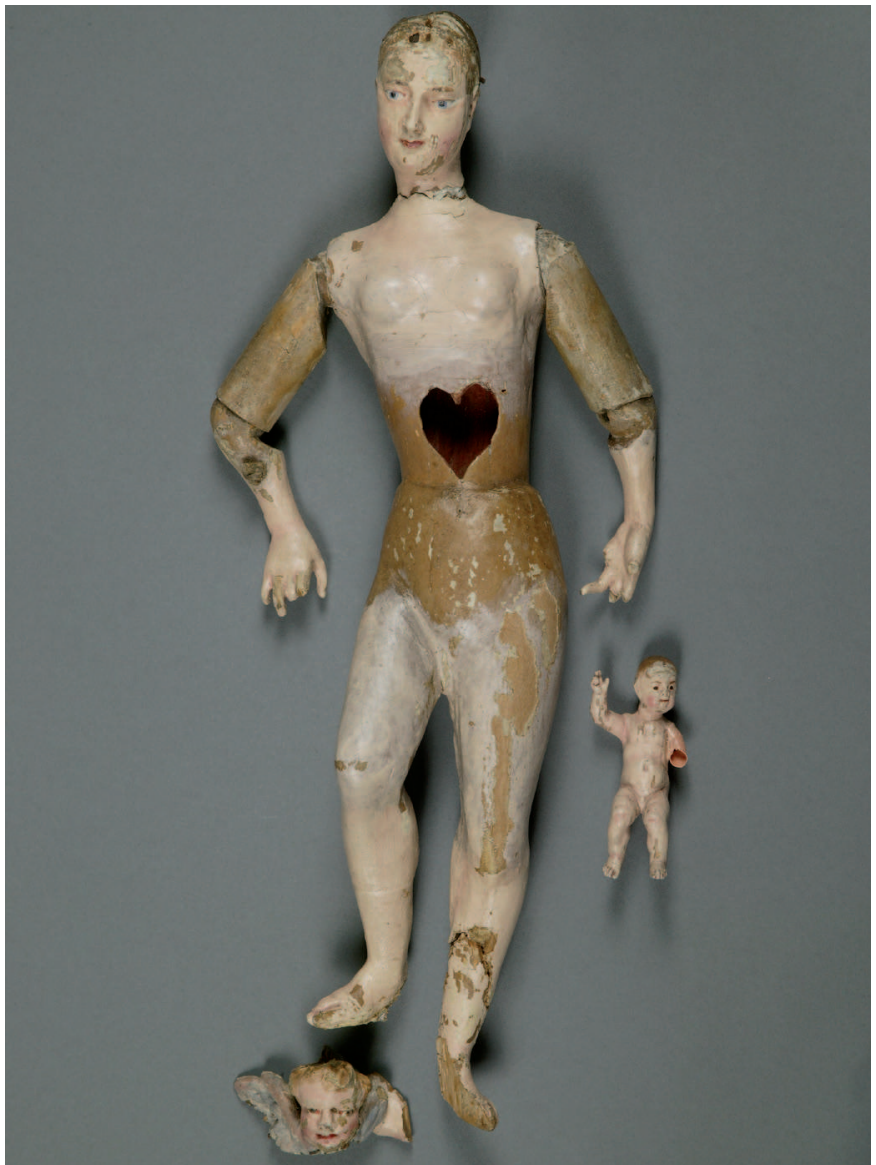

Il. 3. Rzeźby Madonny i Dzieciątka po demontażu i wstępnym oczyszczeniu (fot. W. Grzesik)

a)

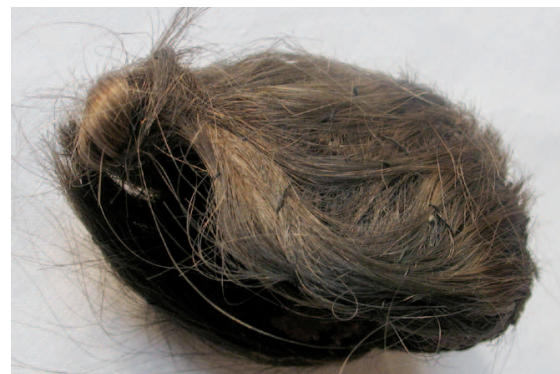

b)

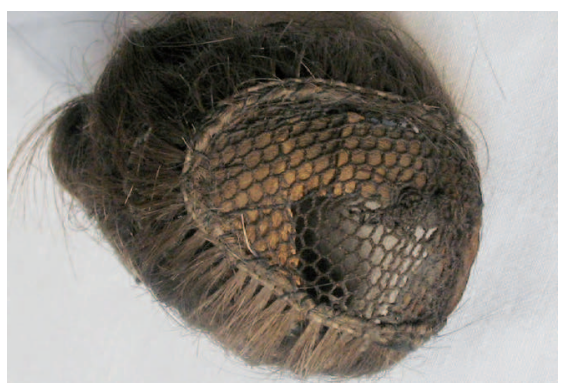

Il. 4. Peruka rzeźby Madonny, stan przed konserwacją: a) zabrudzenia i kształt „fryzury” utrwalony nićmi; b) sposób wykonania - górna część siatkowego czerepu (przysłaniana nakryciem głowy), bez pasm włosów (fot. E. Szmit-Naud) 

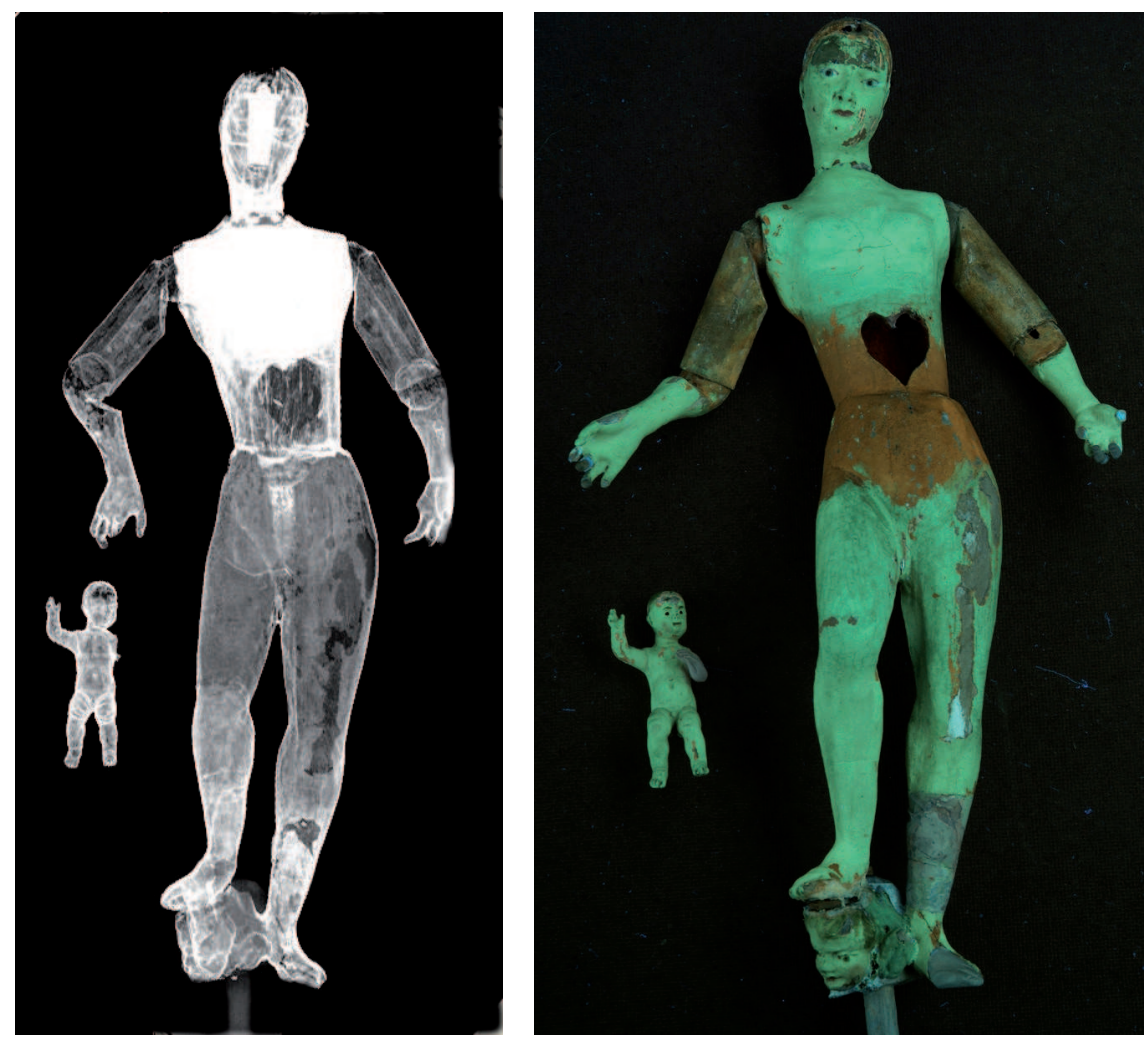

Il. 5. Rentgenogram rzeźb Madon- Il. 6. Fluorescencja w UV powierzchni polichrony i Dzieciątka (wyk. E. Szmit- mii rzeźb Madonny i Dzieciątka (fot. A. Cupa) -Naud na podstawie rentgenogramu) 


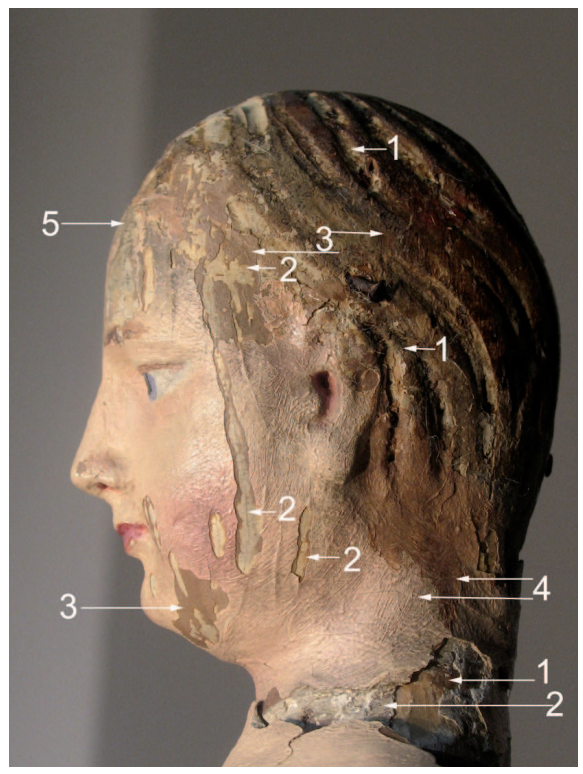

Il. 7. Fragment rzeźby - głowa Madonny, lewy profil. Kolejne polichromie i stan ich zachowania (fot. E. Szmit-Naud):

1 - warstwy pierwotnego opracowania, zaprawa i szczątki warstwy malarskiej;

2 - pierwsze opracowanie wtórne, zaprawa, fragmenty pierwszego przemalowania;

3 - drugie przemalowanie, zespolone z poprzednim, XVIII w.;

4 -trzecie przemalowanie, częściowe, XIX w.;

5 - czwarte przemalowanie, lokalne, XX w.

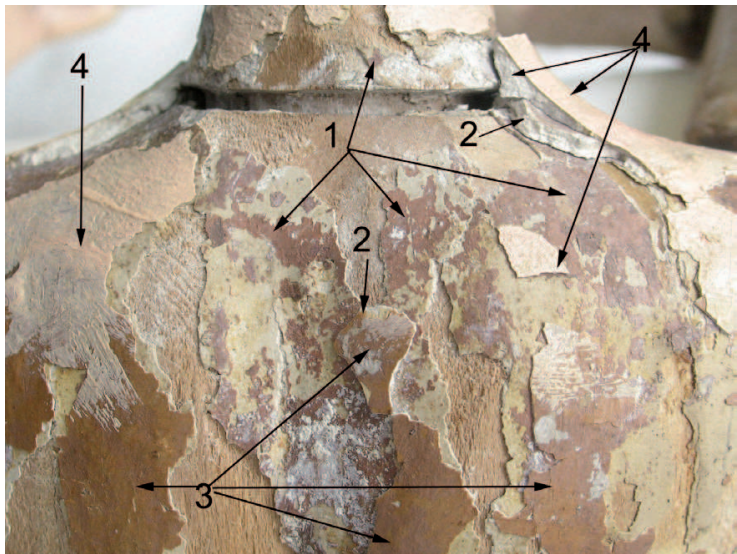

Il. 8. Fragment rzeźby Madonny - górna część pleców i barki. Fragmenty zachowanych opracowań (fot. E. Szmit-Naud):

1 - warstwy pierwotnego opracowania, zaprawa i pozostałości warstwy malarskiej, ciemnoróżowej, brunatnawej, z lokalnie zachowanym werniksem;

2 - pierwsze opracowanie wtórne, zaprawa, na barkach bardzo gruba, fragmenty pierwszego przemalowania;

3 -drugie przemalowanie, zespolone z poprzednim, XVIII w.;

4 - trzecie opracowanie wtórne, częściowe, w obrębie barków na grubej zaprawie, XIX w. 


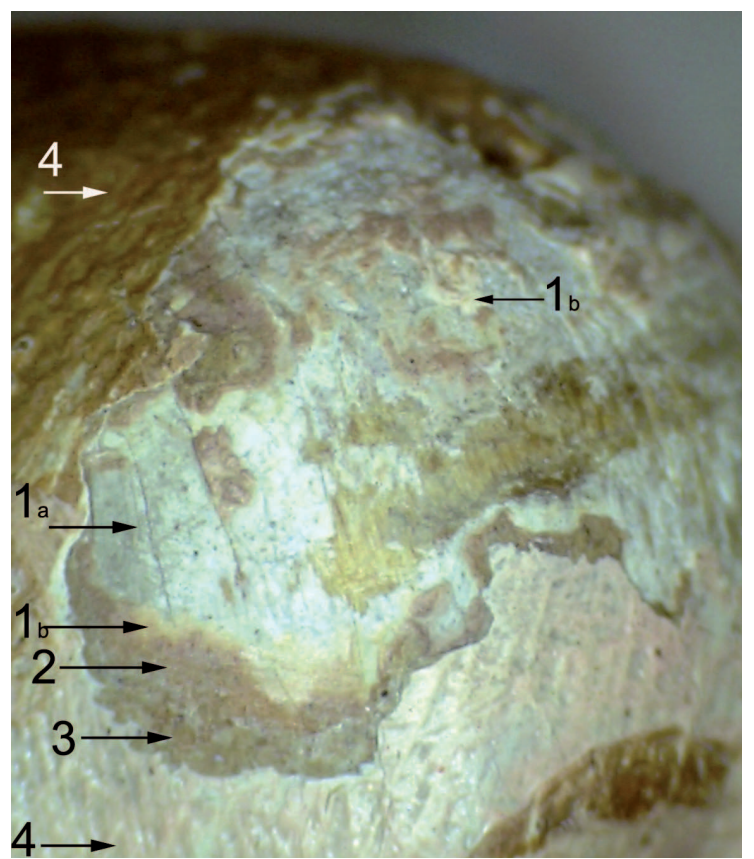

Il. 9. Fragment rzeźby Dzieciątka - prawa skroń. Makrofotografia ubytków i odkrywki poszczególnych polichromii (fot. E. Szmit-Naud):

1a - biała zaprawa pierwotna;

$1 \mathrm{~b}$ - pozostałości pierwotnej warstwy malarskiej;

2 - pierwsze przemalowanie;

3 - drugie przemalowanie;

4 - trzecie przemalowanie

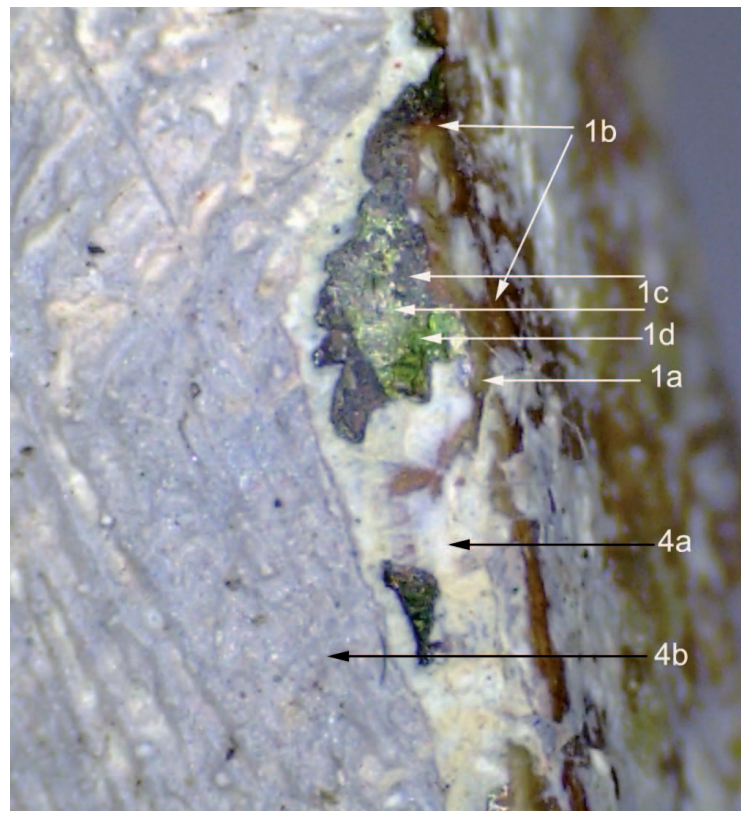

Il. 10. Fragment rzeźby Madonny - krawędź skrzydła putta. Makrofotografia, pozostałości oryginalnej polichromii w ubytku warstw wtórnych (fot. E. Szmit-Naud):

1a - zaprawa oryginalna;

$1 \mathrm{~b}$ - pulment;

1c-srebrzenie, w znacznej części skorodowane;

1d - zielony laserunek na srebrzeniu 
[286]

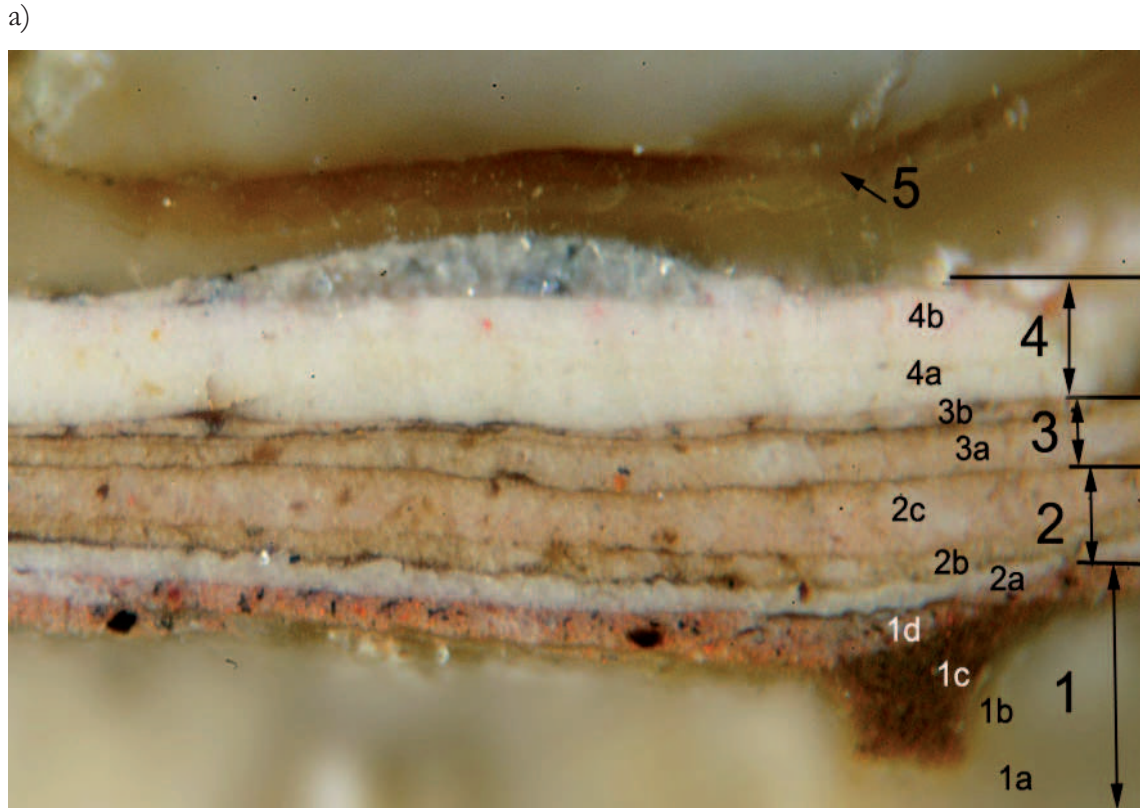

b)

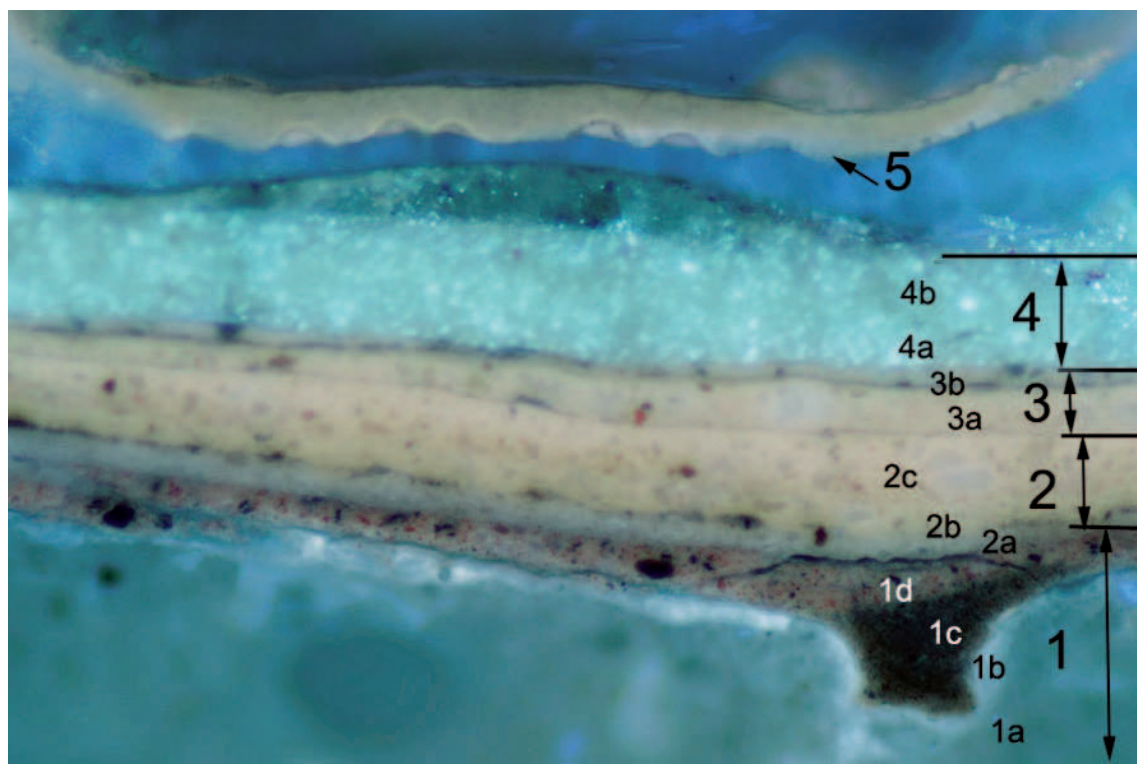




\section{c)}

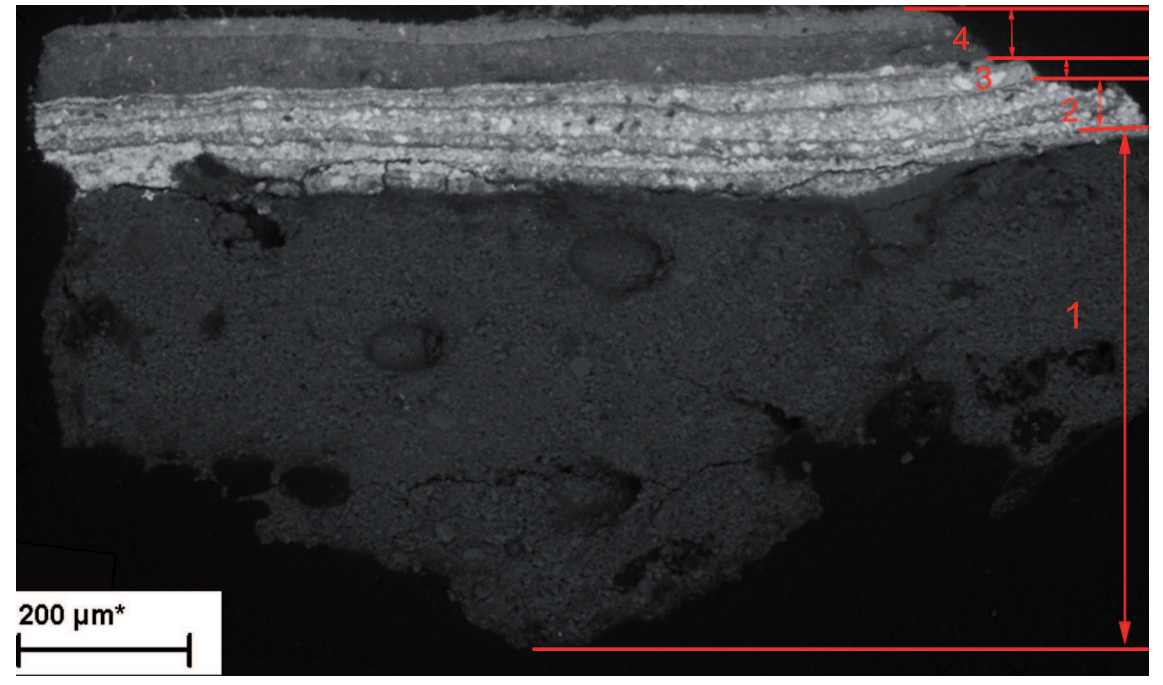

d)

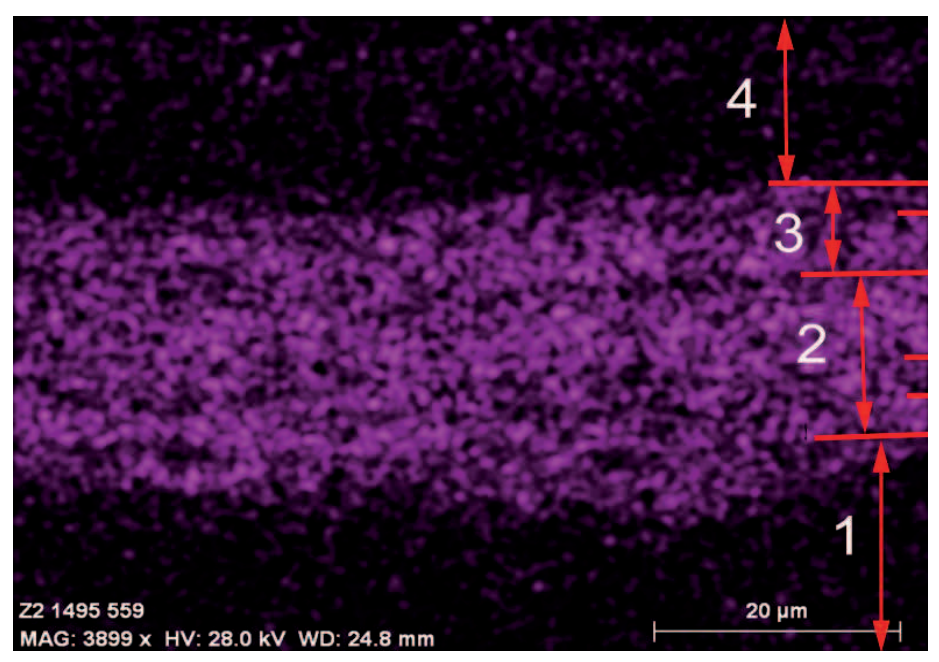


e)

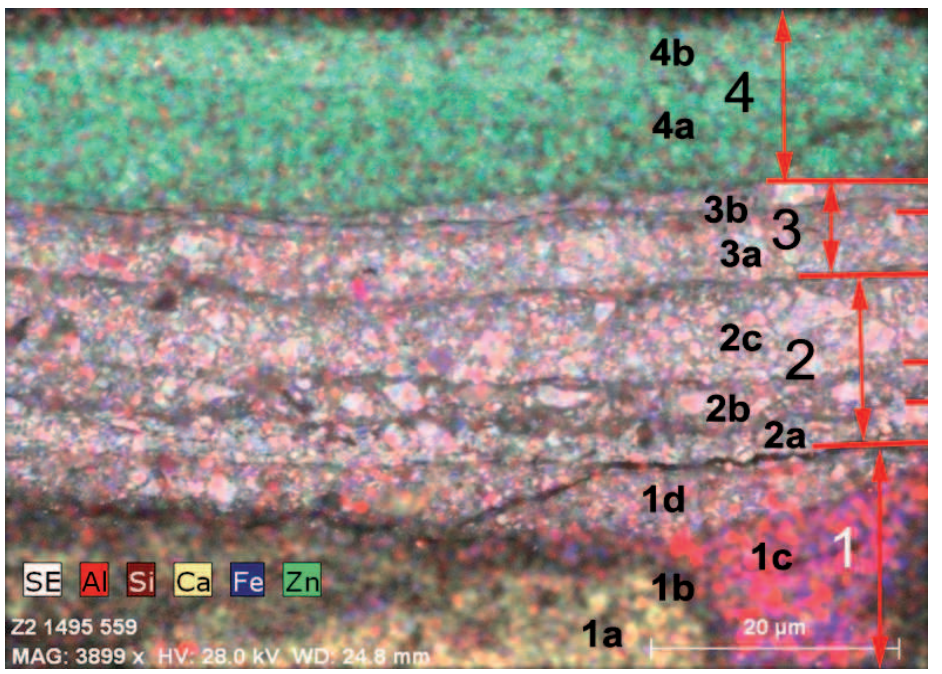

Il. 11. Przekrój próbki pobranej z karnacji Madonny, na prawej stopie: a) fotografia mikroskopowa VIS; b) fotografia mikroskopowa fluorescencji w UV; c), d), e) skany SEM-EDS z oznaczeniem poszczególnych pierwiastków (fot. 11a-b Z. Rozłucka, skany 11c-e G. Trykowski, oznaczenia na przekrojach E. Szmit-Naud):

1 - warstwy pierwotne: 1a - zaprawa: weglan wapnia (naturalnego pochodzenia, kreda) $\mathrm{CaCO}_{3}$, klej glutynowy; $1 \mathrm{~b}$ - przeklejenie: klej glutynowy; 1c warstwa izolującego podmalowania - ziemne brązy żelazowe, $\mathrm{Fe}_{2} \mathrm{O}_{3} \cdot \mathrm{MnO}_{2}$, spoiwo olejne; $1 \mathrm{~d}$ - warstwa malarska: biel otowiana $2 \mathrm{PbCO}_{3} \cdot \mathrm{Pb}(\mathrm{OH})_{2}$, czervien żelazowa $\mathrm{Fe}_{2} \mathrm{O}_{3}$, braz żelazony - umbra $\mathrm{Fe}_{2} \mathrm{O}_{3} \cdot \mathrm{MnO}_{2}$ (domieszka), czerń organiczna, roślinna, temperowe thuste: olej lniany z dodatkiem białka i innym nieokreślonym dodatkiem;

2 - pierwsze opracowanie wtórne; $2 \mathrm{a}$ - zaprawa: weglan wapnia (naturalnego pochodzenia, kreda) $\mathrm{CaCO}_{3}$, biel otowiana $2 \mathrm{PbCO}_{3} \cdot \mathrm{Pb}(\mathrm{OH})_{2} ; 2 \mathrm{~b}, 2 \mathrm{c}$ - warstwa malarska przemalowania: biel otowiana $2 \mathrm{PbCO}_{3} \cdot \mathrm{Pb}(\mathrm{OH})_{2}$, pigmenty żelazowe: ugier $\mathrm{Fe}(\mathrm{OH})_{3}$, czerwień $\mathrm{Fe}_{2} \mathrm{O}_{3}$, braz, umbra palona $\mathrm{Fe}_{2} \mathrm{O}_{3} \cdot \mathrm{MnO}_{2}$, czerń organiczna (domieszka);

3 - drugie opracowanie wtórne: $3 \mathrm{a}, 3 \mathrm{~b}$ - warstwy malarskie przemalowania: skład jak 2;

4 - trzecie opracowanie wtórne: $4 \mathrm{a}$ - podmalowanie: biel cynkowa $\mathrm{ZnO}$, ugier $\mathrm{Fe}(\mathrm{OH})_{3}$ (domieszka); 4b - warstwa malarska przemalowania: biel cynkowa $\mathrm{ZnO}$, biel otowiana $2 \mathrm{PbCO}_{3} \cdot \mathrm{Pb}(\mathrm{OH})_{2}$, ugier $\mathrm{Fe}(\mathrm{OH})_{3}$, czerwień żelazowa $\mathrm{Fe}_{2} \mathrm{O}_{3}$ (domieszki), spoiwo tłuste olejne (pokost);

5 - warstwa zachlapania wtórnym klejem 
a)

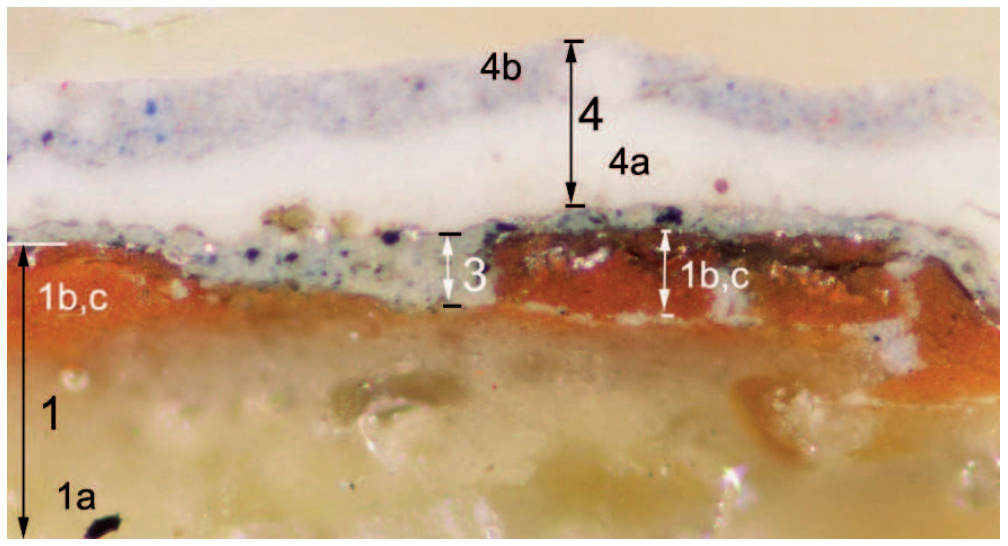

b)

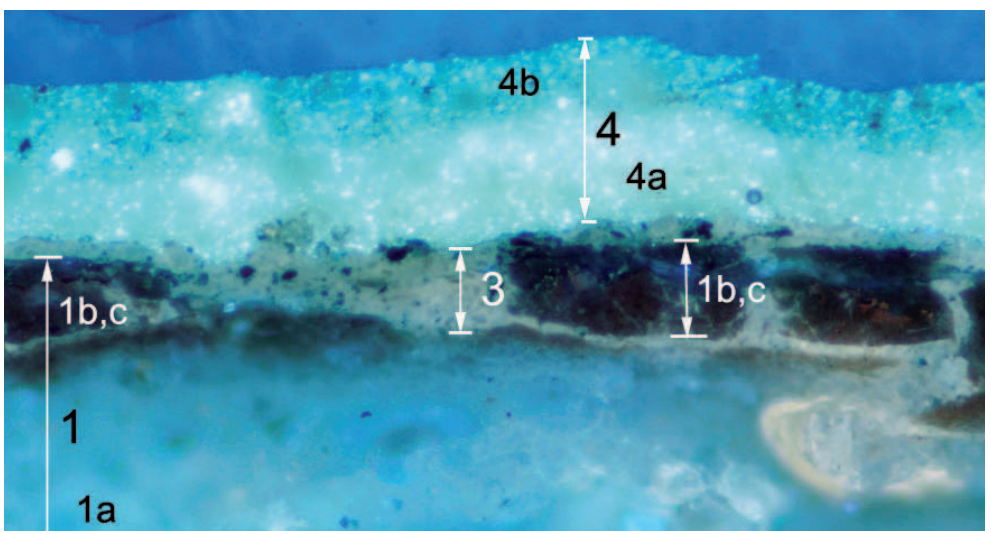

Il. 12. Przekrój próbki pobranej z obłoku za puttem: a) fotografia mikroskopowa VIS; b) fotografia mikroskopowa fluorescencji w UV (fot. Z. Rozłucka, oznaczenia na przekrojach E. Szmit-Naud):

1 - warstwy pierwotne: 1a - zaprawa: weglan wapnia (naturalnego pochodzenia, kreda) $\mathrm{CaCO}_{3}$, klej glutynowy; 1b, 1c - pulment glinka żelazowa, fragmenty folii srebrnej $A g$;

3 - warstwy drugiego przemalowania (pierwsze w tej strefie nie występuje): biel otowiana $2 \mathrm{PbCO}_{3} \cdot \mathrm{Pb}(\mathrm{OH})_{2}$, indygo $\mathrm{C}_{16} \mathrm{H}_{10} \mathrm{~N}_{2} \mathrm{O}_{2}$, czerń organiczna (domieszka), sproszkowana folia srebrna $A g^{\circ}$, spoiwo temperowe tłuste;

4 - trzecie opracowanie wtórne: $4 \mathrm{a}$ - podmalowanie: biel cynkowa $\mathrm{ZnO}$, biel otowiana $2 \mathrm{PbCO}_{3} \cdot \mathrm{Pb}(\mathrm{OH})_{2}$, ugier $\mathrm{Fe}(\mathrm{OH})_{3}$, spoiwo thuste temperowe; $4 \mathrm{~b}$ - warstwa malarska przemalowania: biel cynkowa $\mathrm{ZnO}$, biel otowiana $2 \mathrm{PbCO}_{3} \cdot \mathrm{Pb}(\mathrm{OH})_{2}$, ultramaryna sztuczna $\mathrm{Na}_{8-10} \mathrm{Al}_{6} \mathrm{Si}_{6} \mathrm{O}_{24} \mathrm{~S}_{24}$, czerwień zelazowa $\mathrm{Fe}_{2} \mathrm{O}_{3} \mathrm{i}$ czerń roślinna (domieszki) 
a)

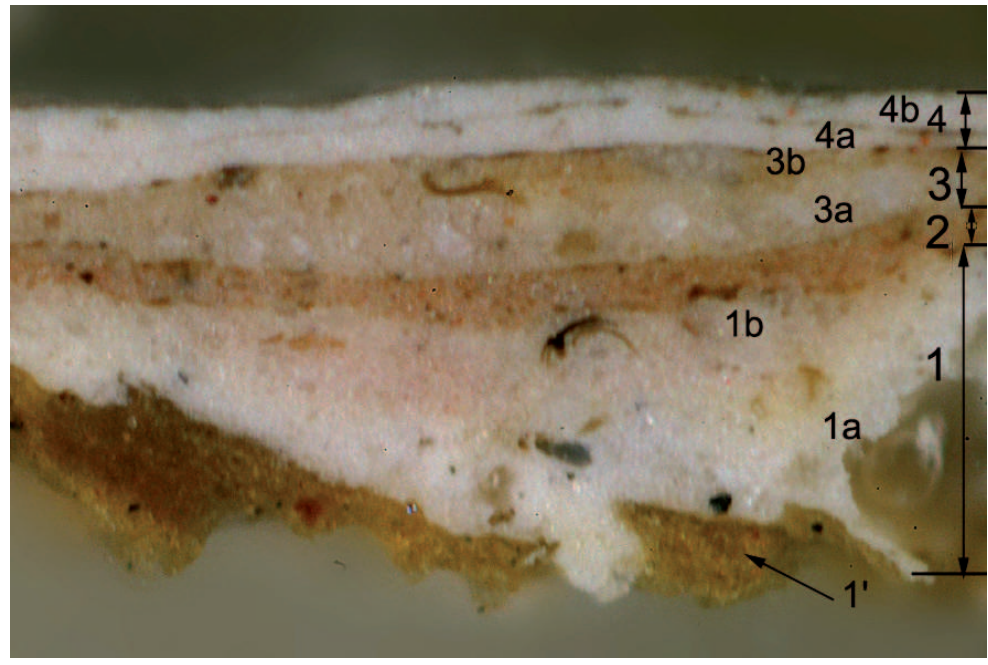

b)

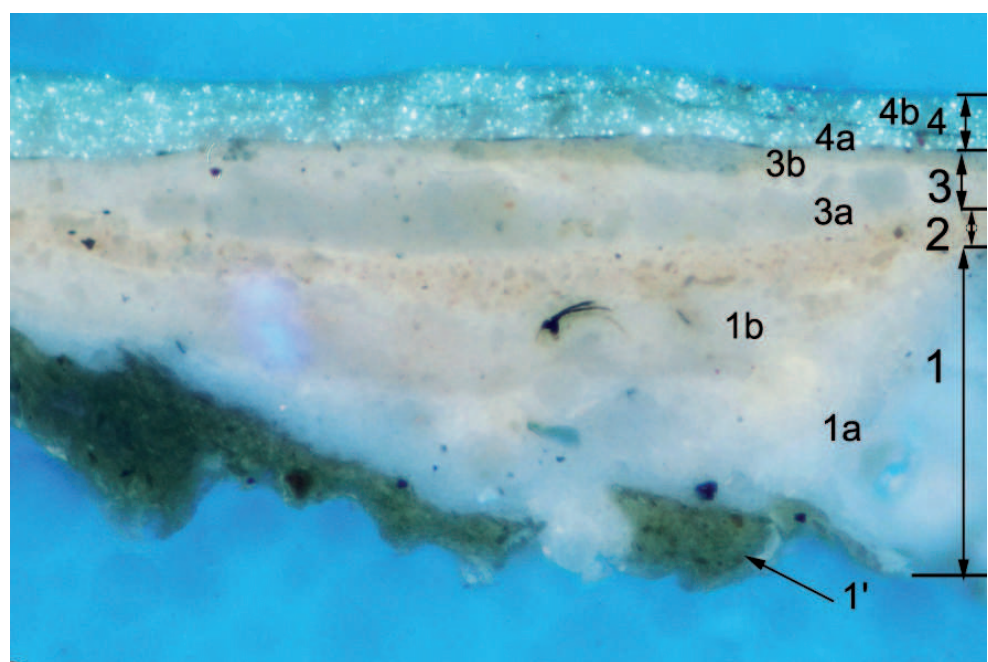

Il. 13. Przekrój próbki pobranej z karnacji rzeźby Dzieciątka: a) fotografia mikroskopowa VIS; b) fotografia mikroskopowa fluorescencji w UV (fot. Z. Rozłucka, oznaczenia na przekrojach E. Szmit-Naud):

1 - warstwy pierwotne: 1' - warstwa izolująca na drewnie, pigmenty żelazowe; 1a - zaprawa: weglan wapnia (naturalnego pochodzenia, kreda) $\mathrm{CaCO}_{3}$, biel otowiana $2 \mathrm{PbCO}_{3} \cdot \mathrm{Pb}(\mathrm{OH})_{2}$, spoiwo tłuste emulsyjne; $1 \mathrm{~b}$ - oryginalna warstwa malarska: biel otowiana $2 \mathrm{PbCO}_{3} \cdot \mathrm{Pb}(\mathrm{OH})_{2}$, czerwień organicżna (nikła ilość), spoiwo temperowe tłuste;

2, 3, 4 - warstwy wtórne jak w przekroju na il. 11 


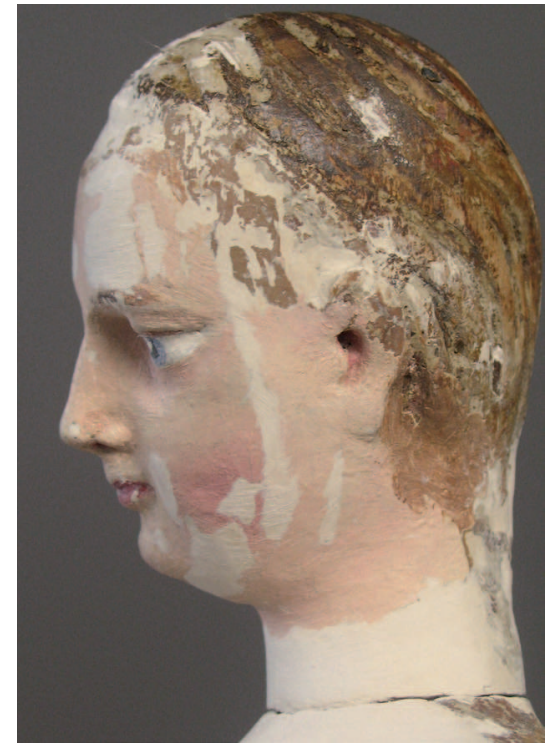

Il. 14. Fragment rzeźby - głowa Madonny, lewy profil, po uzupełnieniu ubytków zaprawy (fot. E. Szmit-Naud)

a)

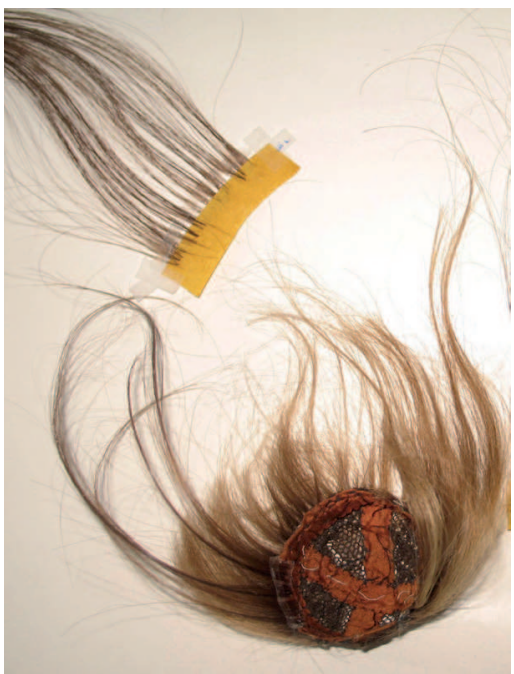

b)

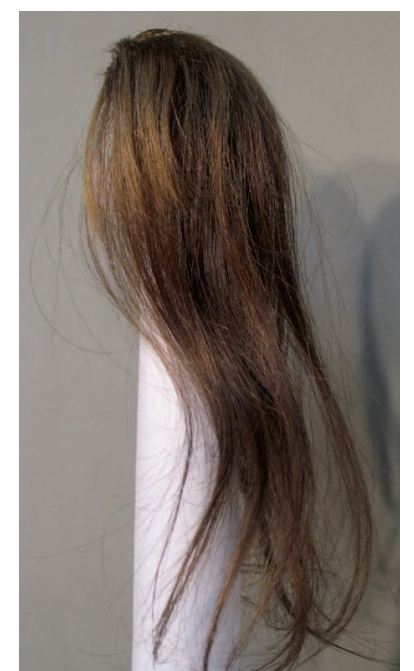

Il. 16. Peruka w trakcie restauracji: a) po oczyszczeniu; uzupełnianie pasm włosów; b) peruka po konserwacji-restauracji (fot. E. Szmit-Naud) 


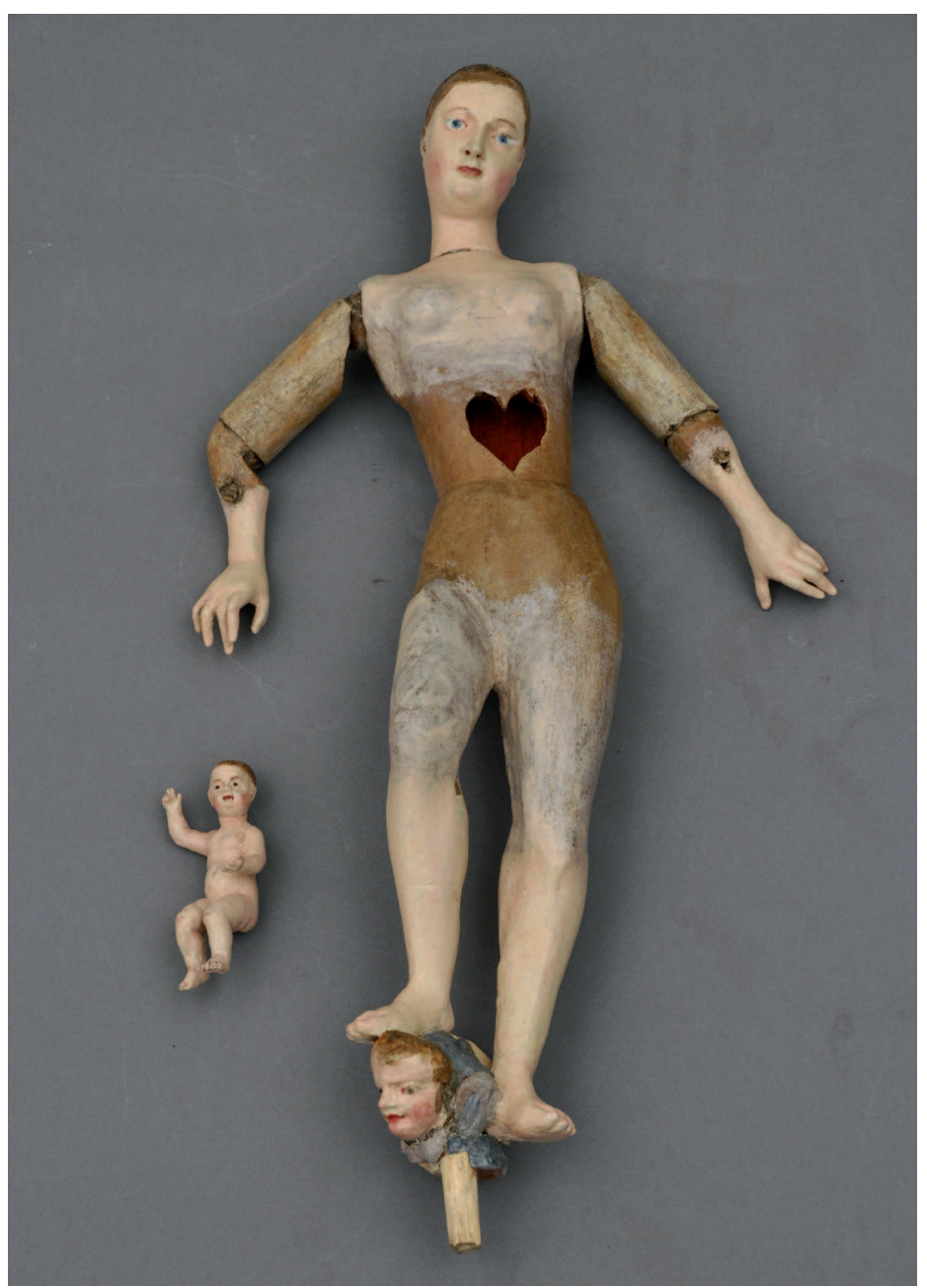

Il. 17. Rzeźby Madonny i Dzieciątka po konserwacji i restauracji (fot. W. Grzesik) 


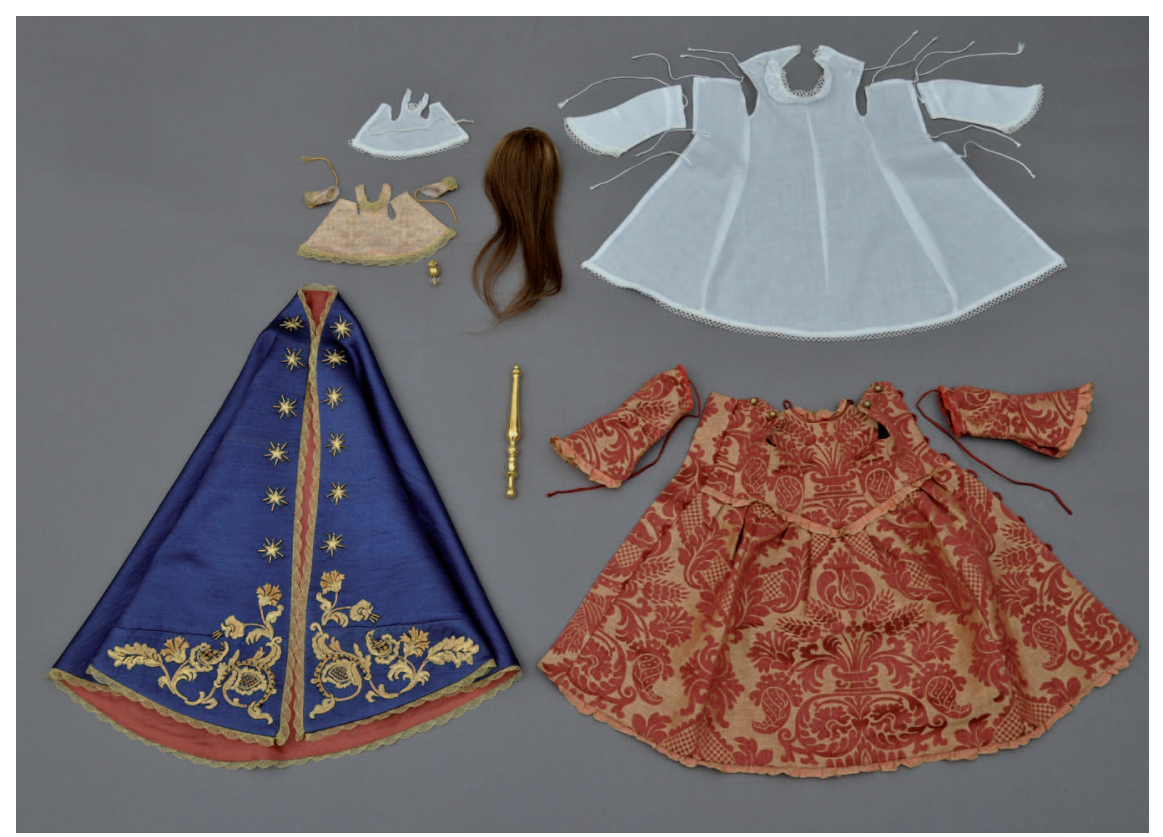

Il. 18. Zrekonstruowane elementy stroju rzeźb (fot. W. Grzesik) 


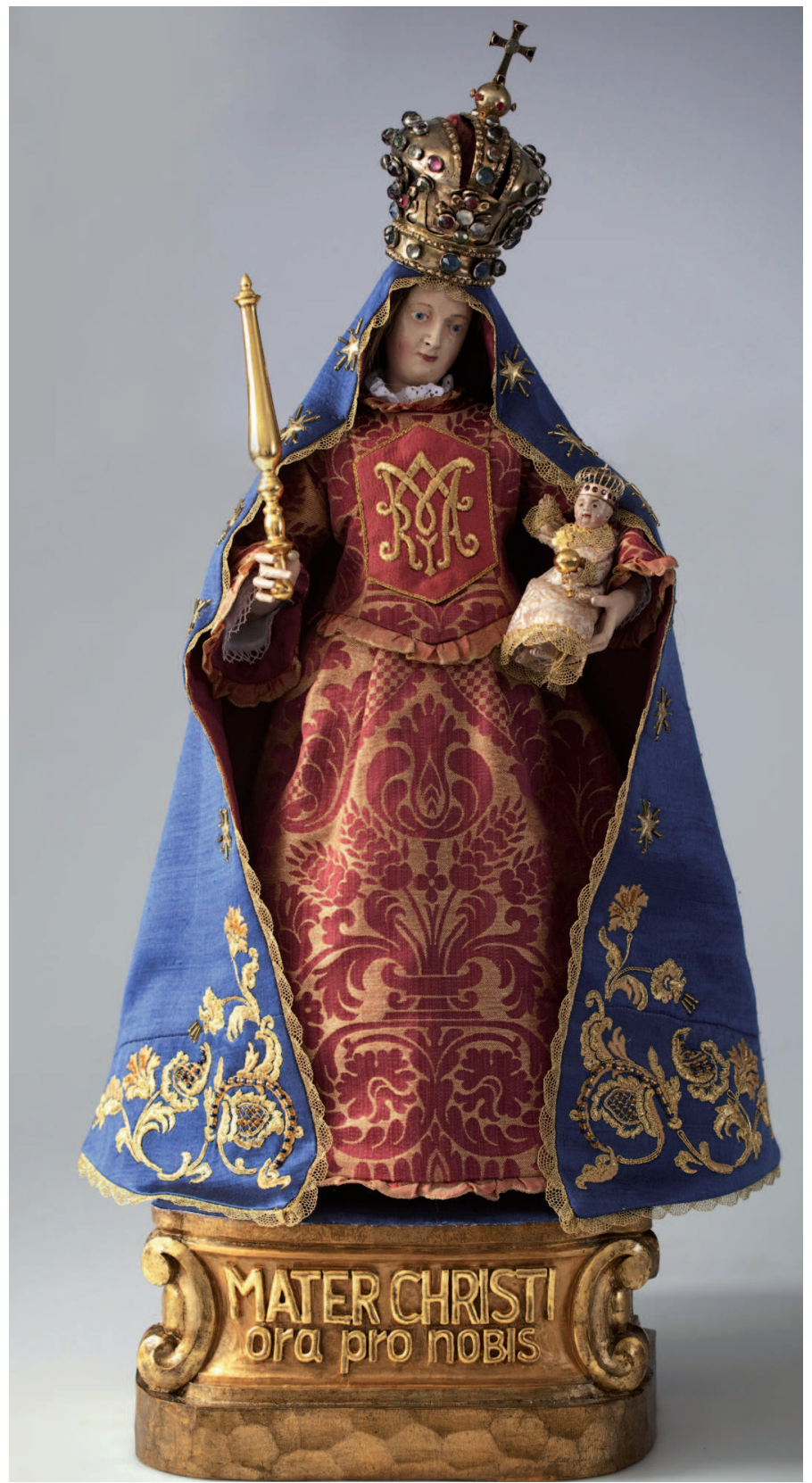

Il. 19. Wizerunek Matki Boskiej Zbrosławickiej po konserwacji-restauracji (fot. J. Renka) 


\section{Summary}

\section{The simulacrum-type figure of Virgin with the Child from Zbrosławice - research and conservation and restoration issues}

The image of Virgin with the Child from the Assumption Church in Zbrosławice (Silesia) belongs among the rare in Poland simulacrum sculptures - with movable limbs, natural hair and dressed in real garments. That little sculpture made about 1700-1750, brought from the Austrian territory, initially served religious devotion in a monastery, later on was an object of private devotion. In the $20^{\text {th }}$ century it became a main artefact of a sanctuary of Virgin Mary, having up to day a very important cult value. The history of the sculpture from its beginning and repeated renovations have in time obliterated its original features, that became illegible due to modification of the image. The carried out research on the figure's structure and a search for analogical artefacts allowed to re-read it and - in the course of conducted conservation and restoration - to approximate the original iconographic conception, with respect for both the limitations of the historic matter and the needs of contemporary cult function. 